medRxiv preprint doi: https://doi.org/10.1101/2021.08.25.21262596; this version posted August 28, 2021. The copyright holder for this preprint (which was not certified by peer review) is the author/funder, who has granted medRxiv a license to display the preprint in perpetuity.

All rights reserved. No reuse allowed without permission.

\title{
Effectiveness of a novel non-intrusive continuous-use air decontamination technology to reduce microbial contamination in clinical settings: A multi-centric study
}

\author{
Savitha Nagaraj ${ }^{1}$, Sindhulina Chandrasingh ${ }^{2}$, Sanju Jose ${ }^{1}$, Sofia $B^{2}$, Sriram Sampath ${ }^{1}$, Bhuvana Krishna ${ }^{1}$, \\ Indira Menon ${ }^{2}$, Debosmita Kundu ${ }^{3}$, Sandeepan Parekh ${ }^{3}$, Deepak Madival ${ }^{3}$, Vrinda Nandi $^{3}$, Arindam \\ Ghatak $^{3 *}$ \\ Affiliations \\ 1. St John's Hospital and Medical College, Bangalore, Karnataka, India \\ 2. Bangalore Baptist Hospital, Bangalore, Karnataka, India \\ 3. Biomoneta Research Private Limited, Bangalore, Karnataka, India
}

\section{* Correspondence : arindam@biomoneta.com}

\begin{abstract}
Background: Despite rigorous disinfection, fumigation and air treatment, infectious microbial load has been found to circulate and survive for significant durations in health care settings. This raises significant concerns for hospital acquired infections. We have developed a novel, hybrid, trap-and-kill airborne-microbicidal technology called "ZeBox" which is efficient in clearing $99.999 \%$ of airborne microbial load under controlled lab conditions. In this study we evaluate the clinical performance of the ZeBox in reducing airborne and surface microbial load in two independent hospital settings.
\end{abstract}

Methods: The studies were conducted in single bed and multi bed ICU of two hospitals. Airborne and surface microbial loads were collected at pre-determined sampling sites pre- and postdeployment of the ZeBox enabled device. The Normality of data distribution was determined using the Shapiro-Wilk test. Statistical significance was determined using Students' T test and Mann-Whitney's U test. Pathogenic and opportunistic organisms were characterized using $16 \mathrm{~S}$ rDNA sequencing. Furthermore, the antibiotic sensitivity of the isolated organisms was tested against current treatments of choice across major antibiotic classes.

Results: Post-deployment, we found statistically significant reductions in both airborne and surface microbial load within the operating range of the ZeBox enabled technology . Across the both hospital ICUs, there was $90 \%$ reduction of airborne microbial load on average, and $75 \%$ reduction of surface microbial load on average, providing a low bioburden zone of roughly 10-15 feet diameter around the unit. These reduced microbial levels were maintained during the entire duration of device operation over several weeks. Many of the clinical isolates recovered from one of the hospitals were drug resistant, which highlighted the potential ability of ZeBox to eliminate drug-resistant microbes and thereby reduce the frequency of hospital acquired infections.

Conclusions: ZeBox enabled technology can significantly reduce a broad spectrum of microbial burden in air and on surfaces in clinical settings. It can thereby serve an unmet need in reducing the incidence of hospital acquired infections. 
medRxiv preprint doi: https://doi.org/10.1101/2021.08.25.21262596; this version posted August 28, 2021. The copyright holder for this preprint (which was not certified by peer review) is the author/funder, who has granted medRxiv a license to display the preprint in perpetuity.

All rights reserved. No reuse allowed without permission.

\section{Background}

Human exposure to environmental organisms is associated with infectious disease transmission as well as allergic and non-allergic respiratory illnesses [1]. The most recent airborne Covid-19 pandemic highlights the continuous crisis caused by biological agents on public health. Even before the current pandemic, Healthcare-associated infections (HAIs) were a growing concern for clinical practice worldwide. Close to 2 million patients contract HAIs in the U.S. every year, out of which nearly 100,000 patients die [2]. The overall HAI rate is about three-fold higher in the developing world, with the risk of contracting device associated infections being as much as 15-19-fold higher [3]. These infections are often due to multidrug-resistant (MDR) bacteria, which have increasingly few treatment options $[3,4]$. Additionally, the risk of contracting HAIs increases if the prior bed or room occupant suffered from infection; this risk is as much as four-fold higher for an Acinetobacter infection [5].

Microbial load in indoor environments can have various origins including shedding from occupant's respiratory tract or skin, aerosolization from showers, or similar systems [6-8]. Quite often, bacteria, viruses, fungi, or fungal spores can also be resuspended from floors and deposited on interior surfaces distant from the source of contamination via airborne dispersion and can be further dispersed via contact with healthcare workers and through cross-contamination $[9,10]$. Pathogenic microorganisms can survive in indoor environments for long periods of time [11] depending on the temperature and humidity, despite regular cleaning protocols instituted by healthcare spaces. The survivability of an organism is strongly dependent on the nature of the surface. For example, SARs-CoV-2 can survive between 2 hours to 28 days depending on the surface, ambient temperature, humidity and exposure to sunshine [12]. Extended contamination of surfaces can lead to the cumulative 
build-up of pathogens over time, particularly those that are resistant to surface or terminal room disinfection and can pose a significant hazard to the next patient [13]. Under typical heating, ventilation and air conditioning (HVAC) found in hospitals, Clostridium difficile spores, Vancomycin resistant Enterococcus (VRE), Methicillin resistant Staphylococcus aureus (MRSA) and Acinetobacter baumannii have been recovered after 4-5 months with surface contamination levels exceeding the number of bacteria or virions necessary for the transmission of infection $[14,15]$. Causing even more concern for nosocomial spread, it has been found that Pseudomonas can linger on surfaces for as long as 16 months [14].

Hospitals, dental clinics, nursing homes and long-term care facilities typically see a large burden of pathogenic organisms posing a health risk to all occupants. Microbial contamination in hospital wards is concentrated in hard-to-reach surfaces such as the floor under beds and bed wheels as compared to higher levels of a room. This correlates both with the source of infection (patients in beds) and the fact that air trapped under beds and instruments is not efficiently cycled through wall mounted air purification units. There is a pressing need to design microbial decontamination devices that function near microbial reservoirs.

In dental clinics, aerosols generated through drills and scalers can potentially splatter or aerosolise and move within the indoor environment. Body fluids or blood from patients may harbour viruses (such as mumps, measles, rubella, HSV 1 and 2, HIV, HBV, SARSCoV, influenza A H5N1, influenza A H1N1, MERS-CoV or SARs-CoV-2), or bacterial pathogens (such as Mycobacterium tuberculosis or Legionella pneumophilla) some of which can be transmitted through aerosols and water mists [16-22]. Studies in nursing home 
and long-term care-home residents have shown that infections account for $27 \%$ to $63 \%$ of hospitalizations in the United States [23].

Reducing the load of pathogenic organisms to below infectious level is thus crucial to mitigate risk of infection, particularly in indoor spaces. The CDC recommends eliminating microbes at the source as they are produced as the first line of defense against the spread of infections [18]. This aspect has come into greater focus more recently with the rapid spread of coronavirus disease across the globe. Indoor air decontamination is an urgent medical need to maintain health and hygiene needs of occupants.

Currently available technologies for decontaminating room air belong to two broad categories: those which merely trap suspended matter in air (inanimate dust particles along with microbes) and those which are microbicidal. Each of these technologies have their merits and demerits, which have been reviewed in considerable detail by others [24-29].

We believe that an ideal air decontamination technology must trap and then kill microbes in situ, thus preventing any future growth and dissemination. While trap-and-kill microbicidal technologies are already available-UV irradiated filters, filters made of microbicidal fibers, and filters combined with plasma technology -they suffer from major demerits regarding flow permeability (which determines power consumption) and generation of toxic by-products during operation. We have developed a novel, hybrid, trapand-kill airborne-microbicidal technology called "ZeBox", which exploits the fact that microbes naturally possess net electric charge (characterized by their zeta-potential) and therefore they can be readily manipulated using an electric field. In ZeBox technology, a non-ionizing electric field is applied between electrode-plates on which unique microbicidal substrates are layered. The electric field plays two roles: it attracts the microbes to the 
microbicidal substrate and potentiates the substrate to instantaneously killing the trapped microbes [30].

In an enclosed test chamber under challenge conditions, ZeBox powered devices achieved 6-9- $\log _{10}$ reduction of a broad spectrum of microorganisms (airborne gram positive and gram-negative organisms of ESKAPE group, viruses, vegetative fungi and spores) in 10 minutes, a performance that is at least 1000-fold superior to that reported in the literature. In applications, which almost always consist of a space (enclosed or otherwise) with an unceasing flux of people and patients, a continuous and rapid-action microbicidal device is highly desirable. This is why the superior killing rate of ZeBox technology makes it unique for continuous real-time applications. In this paper, we evaluate the clinical performance of a ZeBox technology powered air decontamination device variant in reducing bacterial and fungal load in air and on surfaces in two independent hospital settings. We also delineate the typical pathogenic and opportunistic organisms found in these settings, to characterize the risk of nosocomial transmission to patients and health care staff. 
medRxiv preprint doi: https://doi.org/10.1101/2021.08.25.21262596; this version posted August 28, 2021. The copyright holder for this preprint (which was not certified by peer review) is the author/funder, who has granted medRxiv a license to display the preprint in perpetuity.

All rights reserved. No reuse allowed without permission.

\section{Methods}

\section{A. Experimental Design for Testing Device Efficiency in Hospital ICUs:}

\section{a) Single Bed and Multi Bed ICU Set Up:}

The studies were conducted in a single bed ICU and multi bed ICU located in two independent hospitals after approval from their Hospital Internal Ethics Committee. Both rooms were mechanically ventilated with filtered and tempered air at $22.6 \pm 1.9^{\circ} \mathrm{C}$ with no humidification. Housekeeping and nursing staff shared routine cleaning duties. Near-patient sites were cleaned by nurses twice daily at 7 am and $7 \mathrm{pm}$ using wipes (Vernacare Tuffie wipes) and detergent $\left(\mathrm{Hospec}^{\mathrm{TM}}\right)$. Terminal cleaning of the bed-space was performed following discharge. Samples were collected at specific locations identified as sampling sites between 2-3 pm, 7-8 hours post-cleaning of near-patient surfaces three or four times a week. In the Single Bed ICU, samples were collected four times a week over 11 weeks for determining baseline levels of contamination. The ZeBox powered air decontamination device was deployed at the end of the 11th week and samples were collected as before for another 10 weeks.

In the Multi bed ICU, samples were collected three times a week, over 13 weeks for determining baseline levels of contamination. The ZeBox powered air decontamination device was deployed at the end of the 13th week and samples were collected as before for another 13 weeks.

\section{b) Selection of Sampling Sites:}

\section{i. $\quad$ Single Bed ICU}

The room had a dimension of $15 \times 10$ feet (Fig 1a). Indoor air samples were collected at positions S1 (medicine and reporting table) which was 10 feet away and S2 which was 6 feet away from the air decontamination device . Surface samples were collected from 
position S1 (medicine and reporting table) which was 10 feet away and position S3 (patient bed rails) which was 4 feet away from the ZeBox technology powered air decontamination device.

\section{ii. Multi bed ICU}

The room had a dimension of 30 feet $\mathrm{x} 90$ feet. The sampling sites were chosen in consultation with the ICU staff to ensure the deployed device did not hinder movement and activities within the ICU. Sampling sites were selected such that two sites (positions 1 and 2) were proximal to the ZeBox technology powered air decontamination unit and served as sites on which the direct effect of the device could be monitored. Two other sites (positions 3 and 4) were distal to the ZeBox technology powered air decontamination uni and served as the control sampling sites (Figure 1b). The deployed unit (marked by a green circle) could effectively serve an area of 150sq. $\mathrm{ft}$. 
(a)

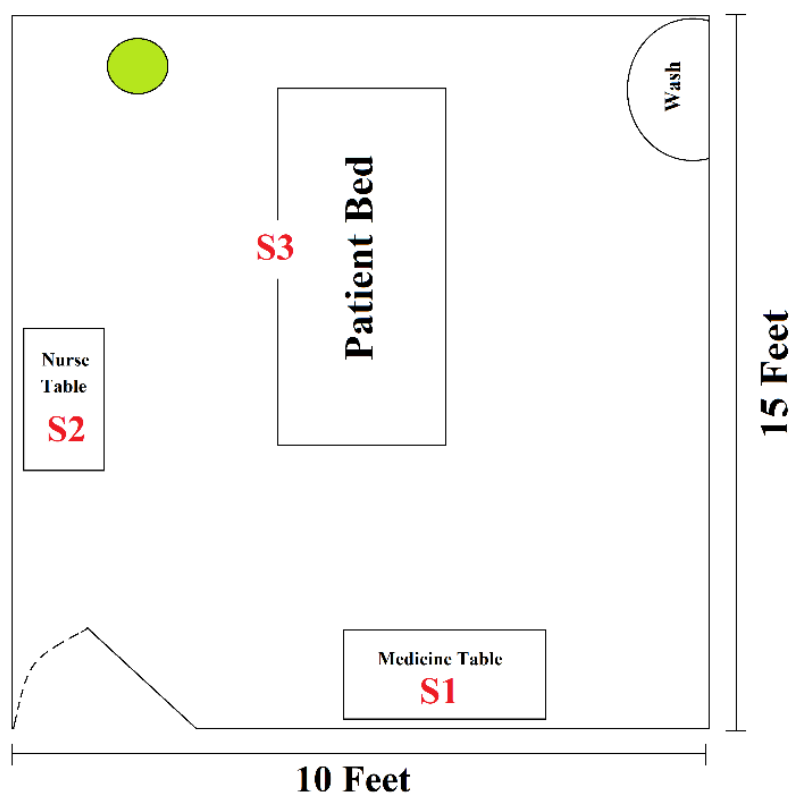

(b)

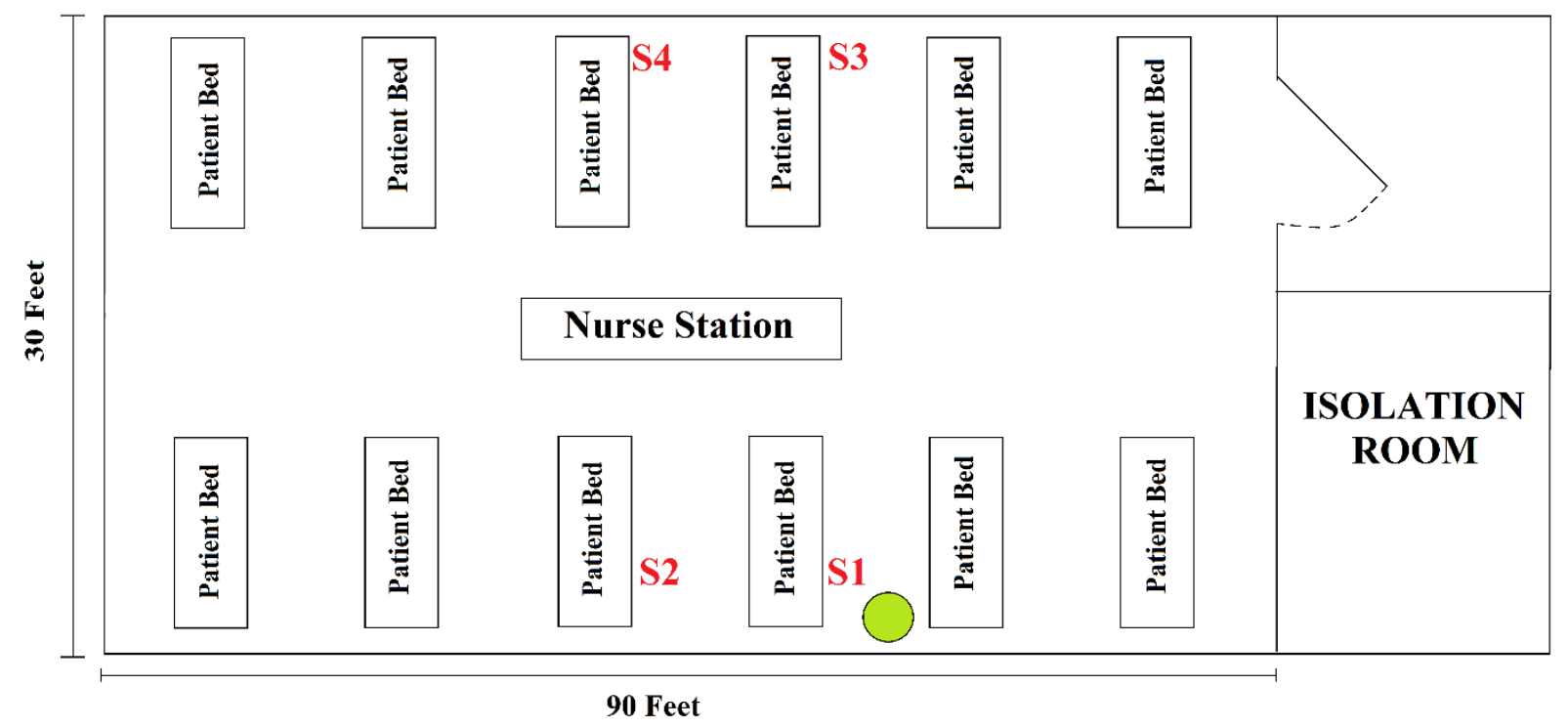

Figure 01 . (a) ICU Room schematics for collecting air samples. The room has a dimension of $15 \times 10 \mathrm{ft}$, samples were collected from positions $\mathrm{S} 1$ and $\mathrm{S} 2$ for quantification of total bacterial and fungal population. Position S1 and S2 were 10 Feet and 6 Feet away from the deployed device respectively. Sample positions S1 and S3 were 10 feet and 4 feet respectively from the deployed device and used for collecting surface microbial samples. 
medRxiv preprint doi: https://doi.org/10.1101/2021.08.25.21262596; this version posted August 28, 2021. The copyright holder for this preprint (which was not certified by peer review) is the author/funder, who has granted medRxiv a license to display the preprint in perpetuity.

All rights reserved. No reuse allowed without permission.

The Green Circle denotes the position of the air decontamination unit. (b) The High Intensity Care Unit (HICU) room layout and the sampling positions $(1,2,3,4)$. The HICU room has a dimension of $90 \mathrm{ft} \times 30 \mathrm{ft}, 12$ patients can be treated in the HICU at any given point. The Green Circle denotes the position of the air decontamination unit. Position 1 was 2 feet away, Position 2 was 8 feet away, Position 3was 24 feet away and Position 4 was 26 feet away from the decontamination device. The deployed unit could effectively serve an area of 150 sq. $\mathrm{ft}$.

\section{B. Sampling of air for viable microbes}

A handheld air sampler (SAS Super ISO 100, VWR), which could sample 100 liters of air per minute, was used to collect air samples. A fixed volume of air was sampled using the air-sampler. Tryptic Soy Agar and Sabouraud dextrose agar plates were used to sample bacteria and fungi, respectively, from the air. Plates were placed in and removed from the air-sampler in an aseptic manner. Plates were incubated at $25 \pm 2^{0} \mathrm{C}$ (for fungal cultivation) and $37 \pm 2^{0} \mathrm{C}$ (for bacterial cultivation) for 48 hours. After incubation, the number of colonies were enumerated and converted to $\mathrm{CFU} / \mathrm{m}^{3}$ using statistical conversion provided by the manufacturer. Control plates were used to ensure the sterility of the entire process.

\section{Surface sampling}

A cotton swab was moistened with sterile phosphate-buffered saline (1X PBS; pH 7.2) solution using aseptic technique to prevent cross-contamination and was used to wipe a surface of $100 \mathrm{~cm}^{2}$ area as mentioned in CDC Guideline (EMERGENCY RESPONSE RESOURCES https://www.cdc.gov/niosh/topics/emres/unp-envsamp.html). The sampled swab was placed in a sterile conical vial containing $1 \mathrm{ml}$ of sterile phosphate-buffered saline 
medRxiv preprint doi: https://doi.org/10.1101/2021.08.25.21262596; this version posted August 28, 2021. The copyright holder for this preprint (which was not certified by peer review) is the author/funder, who has granted medRxiv a license to display the preprint in perpetuity.

All rights reserved. No reuse allowed without permission.

(PBS) solution. The entire $1 \mathrm{ml}$ solution was then plated on to Tryptic Soy Agar and Sabouraud dextrose agar plates for quantification of bacteria and fungi, respectively. Plates were incubated at $25 \pm 2^{0} \mathrm{C}$ (for fungal cultivation) and $37 \pm 2^{\circ} \mathrm{C}$ (for bacterial cultivation) for 48 hours. Post-incubation, the number of colonies that appeared were enumerated. Control plates were used to ensure the sterility of the entire process.

\section{Microbial identification from Multi Bed Hospital ICU using 16S rDNA sequencing:}

Bacterial population from air were collected using a handheld air-sampler on a TSA plate and incubated for 48 hours, allowing the collected microbes to grow and form visible colonies. Colonies were first screened based on their morphological characteristics, (viz texture, color, shape, and elevation) and grouped accordingly. Individual isolates from these groups were then picked for $16 \mathrm{~S}$ rDNA sequencing. The $16 \mathrm{~S}$ rRNA gene region of bacterial genomic DNA was amplified using universal bacterial primers. Each of the PCR reaction systems contained $2 \mu \mathrm{l}$ of Forward primer $(0.4 \mu \mathrm{M}), 5^{\prime}$-AGR GTT TGA TCM TGG CTC AG-3', $2 \mu \mathrm{l}$ of Reverse primer $(0.4 \mu \mathrm{M})$, 5'-GGY TAC CTT GTT ACG ACT T-3', $5 \mu$ l of PCR Green buffer (1X), $1.5 \mu \mathrm{l}$ of $\mathrm{MgCl}_{2}(1.5 \mathrm{mM}), 2.5 \mu \mathrm{l}$ of dNTP $(0.1 \mathrm{mM}), 0.2 \mu \mathrm{l}$ of Taq DNA Polymerase (1 unit), and approximately $7.5 \mathrm{ng}$ of DNA template. It was followed by the addition of $20 \mu \mathrm{l}$ of mineral oil on top of each PCR reaction mixture. The E. coli ATTC 25922 DNA was used as the positive control and PCR master mix with Milli-Q water was used as a negative control. PCR amplicons were sequenced at the The Bangalore Biocluster Next Generation Genomics Facility (TIFR-NCBS, Bangalore, India). The sequence trace files were assembled, trimmed, aligned and manually checked using Bionumerics software 6.0 (Applied. Maths. Sint-Martens Latem, Belgium), and the sequences were classified using the Classifier and SeqMath tools [31] at the Ribosomal Database Project (RDP) and BLASTn databases via the online interface at National Center of Biotechnology and 
medRxiv preprint doi: https://doi.org/10.1101/2021.08.25.21262596; this version posted August 28, 2021. The copyright holder for this preprint (which was not certified by peer review) is the author/funder, who has granted medRxiv a license to display the preprint in perpetuity.

All rights reserved. No reuse allowed without permission.

Information (NCBI). Sequenced genes were aligned using Clustal Omega (https://www.ebi.ac.uk/Tools/msa/clustalo/) and taxonomical analysis were carried out simultaneously.

\section{E. Antibiotic sensitivity test of microbes collected from Multi Bed HICU}

Single colony of each strain was grown in M9 medium. All test compound stocks and dilutions were prepared in DMSO. Serial two-fold dilutions of antibiotics were prepared separately, with concentrations ranging from $2 \mathrm{mg} / \mathrm{mL}$ to $0.015 \mathrm{mg} / \mathrm{mL}$. To $150 \mu 1$ (3$7 \times 10^{5} \mathrm{CFU} / \mathrm{ml}$ ) of bacterial culture in 96 well microtiter plates, $3 \mu \mathrm{L}$ compound from each of the dilutions was added into respective wells to obtain final concentrations ranging from $40 \mu \mathrm{g} / \mathrm{mL}$ to $0.3 \mu \mathrm{g} / \mathrm{mL}$ of the test compounds. Media control, culture control and appropriate reference drug controls were included. The plates were packed in gas permeable polythene bags and incubated at $37^{\circ} \mathrm{C}$ overnight. Growth was monitored by checking absorbance at $600 \mathrm{~nm}(\mathrm{~A} 600)$. Minimum inhibitory concentration (MIC) was taken as the concentration that resulted in a growth inhibition of $\geq 80 \%$.

\section{F. Statistical Analysis of Data}

All data sets were tested for normal distribution using Shapiro-Wilk test (SW test), following which a non-parametric test, the "Mann-Whitney's U test" (MWU test) was conducted. The details are available in the Supplementary material. 
medRxiv preprint doi: https://doi.org/10.1101/2021.08.25.21262596; this version posted August 28, 2021. The copyright holder for this preprint (which was not certified by peer review) is the author/funder, who has granted medRxiv a license to display the preprint in perpetuity.

All rights reserved. No reuse allowed without permission.

\section{Results}

\section{A. Validation in Single Bed ICU:}

\section{a) Airborne microorganisms:}

The environmental microbial load was monitored in a single bed ICU room when occupied by patients. Air samples for monitoring baseline load were collected over a period of 11 weeks to enumerate microbial distribution at two locations within the room. This was followed by ZeBox technology powered air decontamination unit deployment and sample collection over a subsequent period of 10 weeks with the first sample collection within a period of 3 hours after device deployment.

The airborne bacterial load before deployment was more or less similar at both the medicine table and nurse station, and showed roughly a four-fold intra-day variation over the period of 11 weeks (Figure 2, Table 1), ranging from 580-3000 CFU/m³ (average $1168 \mathrm{CFU} / \mathrm{m} 3$ ) at the medicine table (S1) and 80-1910 CFU/m³ (average $1147 \mathrm{CFU} / \mathrm{m} 3$ ) at the nurse station (S2). Similarly, the airborne fungal load before deployment showed roughly a three-fold variation day to day over 11 weeks, but on some days, the CFU counts were as high as four to seven-fold from the average daily counts (Figure 3, Table 1). Airborne fungal counts at the medicine table $(\mathrm{S} 1)$ ranged from $78-688 \mathrm{CFU} / \mathrm{m}^{3}$ (average $157 \mathrm{CFU} / \mathrm{m}^{3}$ ) and 72-698 $\mathrm{CFU} / \mathrm{m}^{3}$ (average $168 \mathrm{CFU} / \mathrm{m}^{3}$ ) at the nurse station (S2) before device deployment.

After deployment of the decontamination device, the airborne bacterial load was reduced to $0-470 \mathrm{CFU} / \mathrm{m}^{3}$ at the medicine table (S1) (average $89 \mathrm{CFU} / \mathrm{m}^{3}$ ), and $0-710 \mathrm{CFU} / \mathrm{m}^{3}$ at the nurse station (average $108 \mathrm{CFU} / \mathrm{m}^{3}$ ) (Figure 2, Table 1). This accounts for a $92 \%$ reduction of airborne bacterial load at the medicine table (S1) and a 91\% reduction at the nurse station (S2). The fungal load after deployment reduced to $4-144 \mathrm{CFU} / \mathrm{m}^{3}$ (average $31 \mathrm{CFU} / \mathrm{m} 3$ ) at the medicine table and 4-202 $\mathrm{CFU} / \mathrm{m}^{3}$ (average $42 \mathrm{CFU} / \mathrm{m}^{3}$ ) at the nurse station (Figure 3, 
Table 1). This accounts for $80 \%$ reduction of fungal load at the medicine table and a $75 \%$ reduction at the nurse station. Both airborne bacterial and fungal load dropped significantly within a period of 3 hours post deployment of the device. The device was in continuous operation for the remaining duration of the study.

Airborne Bacterial Load in Single Bed ICU

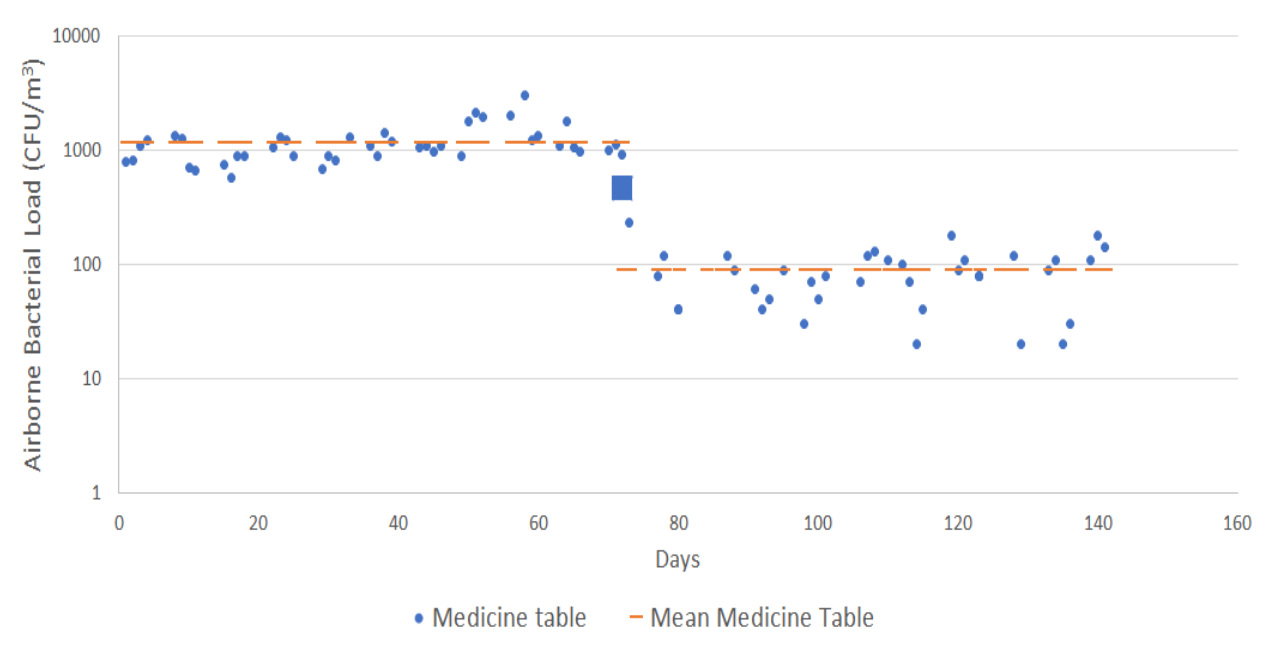

(b)

Airborne Bacterial Load in Single Bed ICU

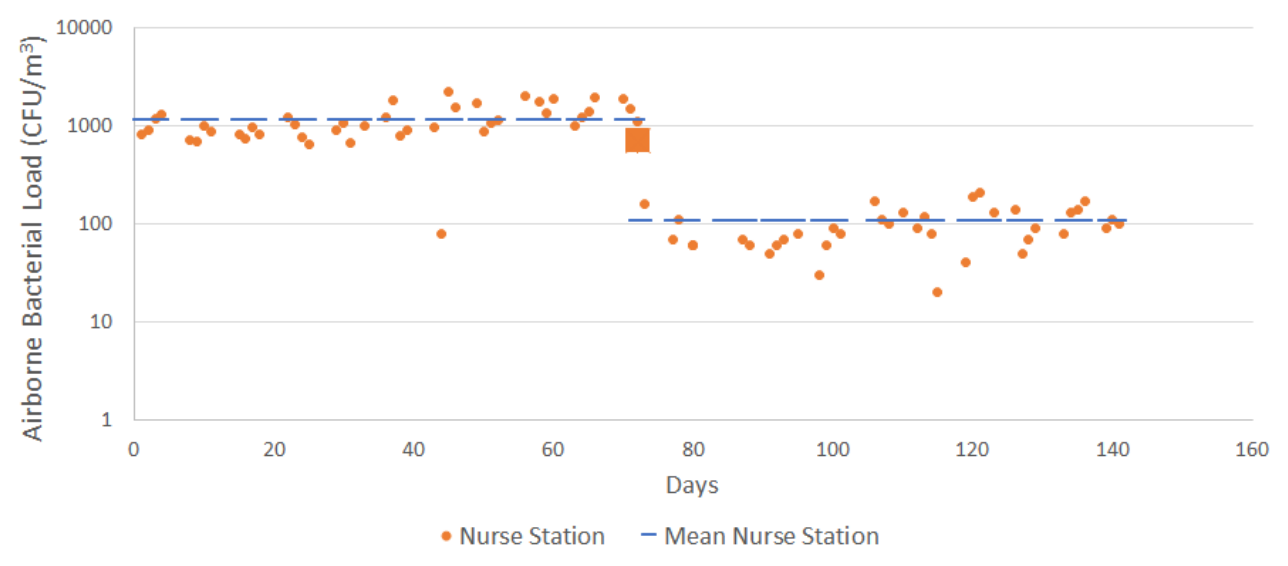

Figure 2 : Airborne Bacterial loads at two positions in the Single Bed ICU.

(a) Position S1, Medicine table and (b) position S2, Nurse Station. The average load before 

that time point is depicted by the square.

(a)

Airborne Fungal Load in Single Bed ICU

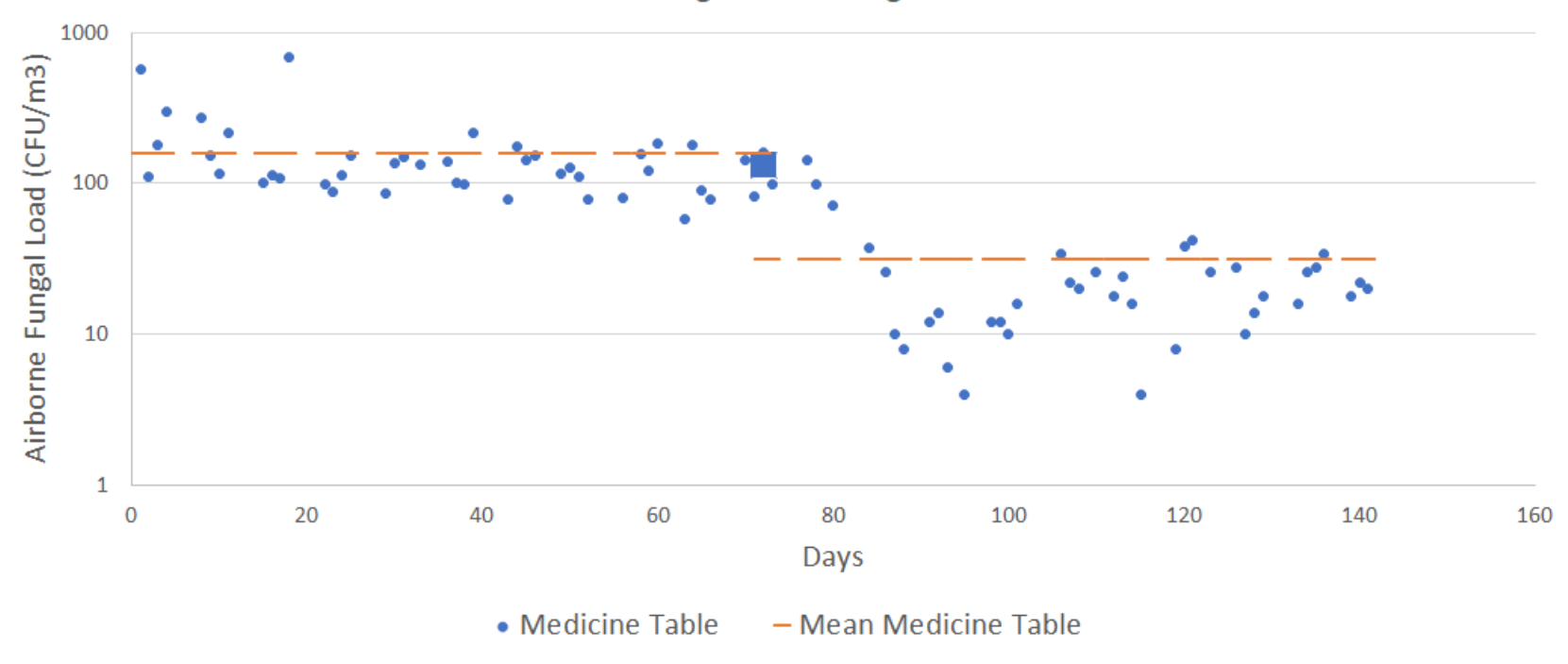

(b)

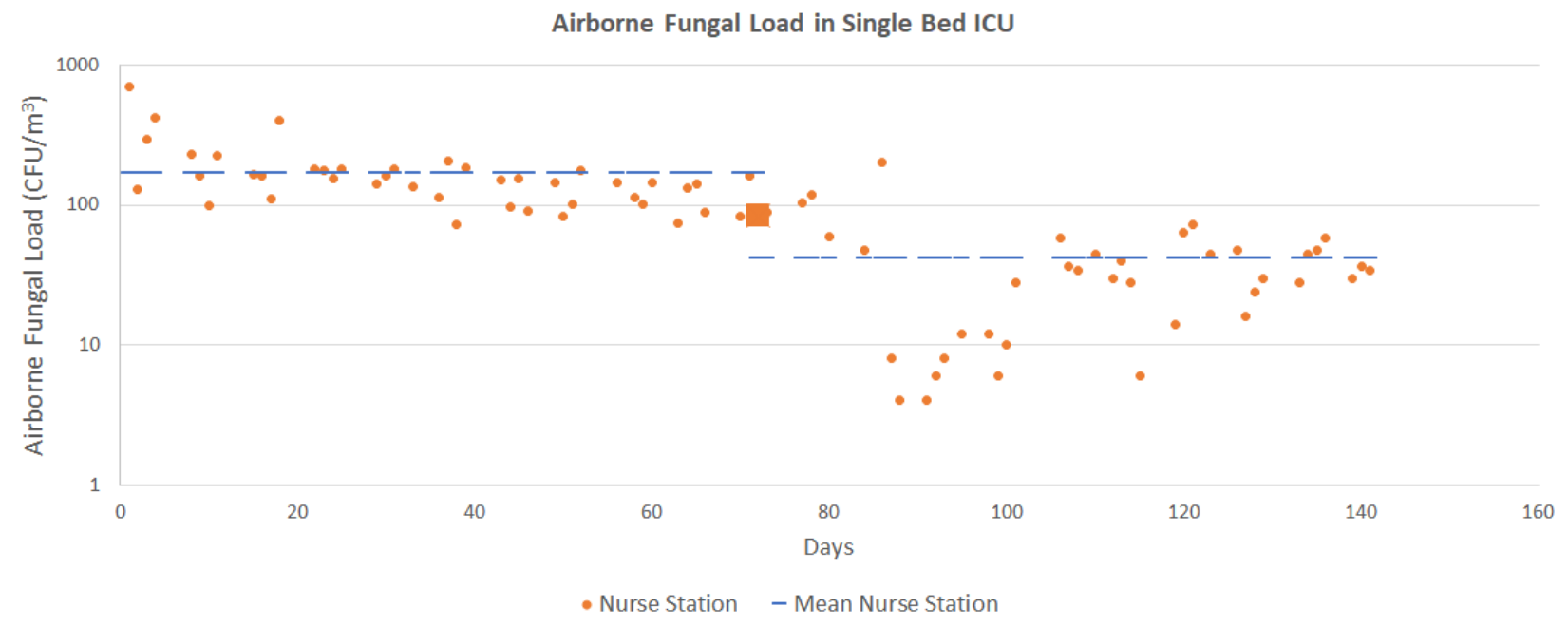

Figure 3: Airborne Fungal Loads at two positions in the Single Bed ICU. 
(a) Position S1, Medicine table and (b) position S2, Nurse Station. The average load before and after ZeBox technology powered air decontamination unit deployment is depicted by a line for both positions. The ZeBox powered air decontamination unit was deployed on day 72 and the first sample was taken within 3 hours of deployment. The microbial count for that time point is depicted by the square.

\section{b) Surface microorganisms:}

Surface samples were collected from the medicine storage table and patient bed rail in the single ICU bed cubicle. Bacterial load before deploying the decontamination device ranged from $1500-9400 \mathrm{CFU} / \mathrm{m}^{2}$ and $200-10500 \mathrm{CFU} / \mathrm{m}^{2}$ on medicine table (S1) and patient bed rails (S3) respectively (Supplementary Figure S1, Table 1). After device deployment, surface bacterial load reduced to 800 - $^{-1900}$ and $200-1900$ on medicine table and patient bed rails respectively. This accounts for a $73 \%$ reduction of surface bacterial load on the medicine table. However, there was considerable scatter in the bacterial load on the bed rails both before and after device deployment and no significant reduction of surface bacterial load ( $\sim 5 \%$ reduction of the mean surface load).

Surface Fungal load before deploying the decontamination device ranged from 400-1100 $\mathrm{CFU} / \mathrm{m}^{2}$ and $0-1300 \mathrm{CFU} / \mathrm{m}^{2}$ on medicine table and patient bed rails, respectively. Postdeployment of the decontamination device, the surface fungal load was reduced to $0-300$ $\mathrm{CFU} / \mathrm{m}^{2}$ on both medicine table and patient bed rails (Supplementary Figure S2, Table 1). This accounts for $84 \%$ reduction of airborne bacterial load at the medicine table and a $74 \%$ reduction on the bed rails. 


\begin{tabular}{|c|c|c|c|c|c|}
\hline \multicolumn{2}{|c|}{} & \multicolumn{2}{c|}{$\begin{array}{c}\text { Airborne Bacterial load } \\
(\text { CFU/m })^{3}\end{array}$} & \multicolumn{2}{c|}{$\begin{array}{c}\text { Airborne Fungal Load } \\
(\text { CFU/m })^{3}\end{array}$} \\
\cline { 3 - 6 } & Medicine table & Nurse Station & $\begin{array}{c}\text { Medicine } \\
\text { table }\end{array}$ & $\begin{array}{c}\text { Nurse } \\
\text { Station }\end{array}$ \\
\hline $\begin{array}{c}\text { Pre- } \\
\text { Deployment }\end{array}$ & Range & $580-3000$ & $80-1910$ & $78-688$ & $72-698$ \\
\hline \multirow{2}{*}{$\begin{array}{c}\text { Post } \\
\text { Deployment }\end{array}$} & Mean & 1168 & 1147 & 157 & 168 \\
\hline & Median & 1080 & 1020 & 128 & 146 \\
\hline & Meange & $0-470$ & $0-710$ & $4-144$ & $4-202$ \\
\hline & Median & 89 & 108 & 31 & 42 \\
\hline & Reduction & 90 & 90 & 20 & 34 \\
\hline
\end{tabular}

\begin{tabular}{|c|c|c|c|c|c|}
\hline & & \multicolumn{2}{|c|}{$\begin{array}{c}\text { Surface Bacterial Load } \\
\left(\mathrm{CFU} / \mathrm{m}^{2}\right)\end{array}$} & \multicolumn{2}{|c|}{$\begin{array}{c}\text { Surface Fungal Load } \\
\left(\mathrm{CFU} / \mathrm{m}^{2}\right)\end{array}$} \\
\hline & & $\begin{array}{l}\text { Medicine } \\
\text { Table }\end{array}$ & Bed rail & $\begin{array}{l}\text { Medicine } \\
\text { Table }\end{array}$ & Bed rail \\
\hline \multirow[t]{3}{*}{$\begin{array}{c}\text { Pre- } \\
\text { Deployment }\end{array}$} & Range & $1500-9400$ & $200-10500$ & $400-1100$ & $0-1300$ \\
\hline & Mean & 4681 & 1667 & 713 & 581 \\
\hline & Median & 3950 & 750 & 700 & 550 \\
\hline \multirow[t]{4}{*}{$\begin{array}{c}\text { Post } \\
\text { Deployment }\end{array}$} & Range & $800-1900$ & 200-1900 & $0-300$ & $0-300$ \\
\hline & Mean & 1269 & 913 & 113 & 150 \\
\hline & Median & 1100 & 700 & 100 & 200 \\
\hline & $\begin{array}{c}\% \\
\text { Reduction }\end{array}$ & 73 & 45 & 84 & 74 \\
\hline
\end{tabular}

Table 1: Descriptive statistics for airborne and surface microbial load in a single bed ICU. The airborne bacterial and fungal loads were measured at medicine table and nurse station. The surface bacterial and fungal loads were measured at medicine table and bed rails. 
medRxiv preprint doi: https://doi.org/10.1101/2021.08.25.21262596; this version posted August 28, 2021. The copyright holder for this preprint (which was not certified by peer review) is the author/funder, who has granted medRxiv a license to display the preprint in perpetuity.

All rights reserved. No reuse allowed without permission.

\section{B. Validation in a Multi Bed HICU:}

\section{a) Airborne microorganisms:}

The environmental microbial load was monitored in a functional multi-bed HICU room occupied by patients with regular movement of hospital personnel. Air samples were collected as mentioned previously and total culturable microbial load was enumerated. Baseline samples were collected over a period of thirteen weeks to understand the microbial distribution at various positions in the room. This was followed by device deployment and sample collection over a period of a further thirteen weeks. Depending on the position sampled, the bacterial and fungal load in the air before deployment showed considerable variability over time. Airborne bacterial load before device deployment ranged from 58-398 $\mathrm{CFU} / \mathrm{m}^{3}$ while the fungal load ranged from $14-130 \mathrm{CFU} / \mathrm{m}^{3}$ across the four positions (Table 2).

After deployment of the decontamination device, the airborne microbial load was reduced to $0-210 \mathrm{CFU} / \mathrm{m}^{3}$ and $0-98 \mathrm{CFU} / \mathrm{m}^{3}$ for bacterial and fungal population, respectively, across the four sampling positions. The maximum reduction in bacterial load in air was shown at Position $1\left(0-66 \mathrm{CFU} / \mathrm{m}^{3}\right)$ and Position $2\left(0-44 \mathrm{CFU} / \mathrm{m}^{3}\right)$, which were 2 and 8 feet away from the ZeBox technology powered air decontamination unit, than at Positions 3 (20-210 $\left.\mathrm{CFU} / \mathrm{m}^{3}\right)$ and Positions $4\left(24-208 \mathrm{CFU} / \mathrm{m}^{3}\right)$, which were 24 and 26 feet away from the device (Figures 4, Table 2). This accounted for a 96-97\% reduction in airborne bacterial load at Positions 1 and 2, but only 40-44\% reduction in airborne bacterial load at Positions 3 and 4.

The trend for airborne fungal load also showed a similar pattern. The maximum reduction was shown at Positions 1 and $2\left(0-18 \mathrm{CFU} / \mathrm{m}^{3}\right)$ as compared with Positions $3\left(0-98 \mathrm{CFU} / \mathrm{m}^{3}\right)$ and Positions $4\left(0-58 \mathrm{CFU} / \mathrm{m}^{3}\right)$. This accounted for $93-94 \%$ reduction of airborne fungi at Positions 1 and 2, but only 51-53\% reduction at Positions 3 and 4 (Figure 5, Table 2). 
(a)

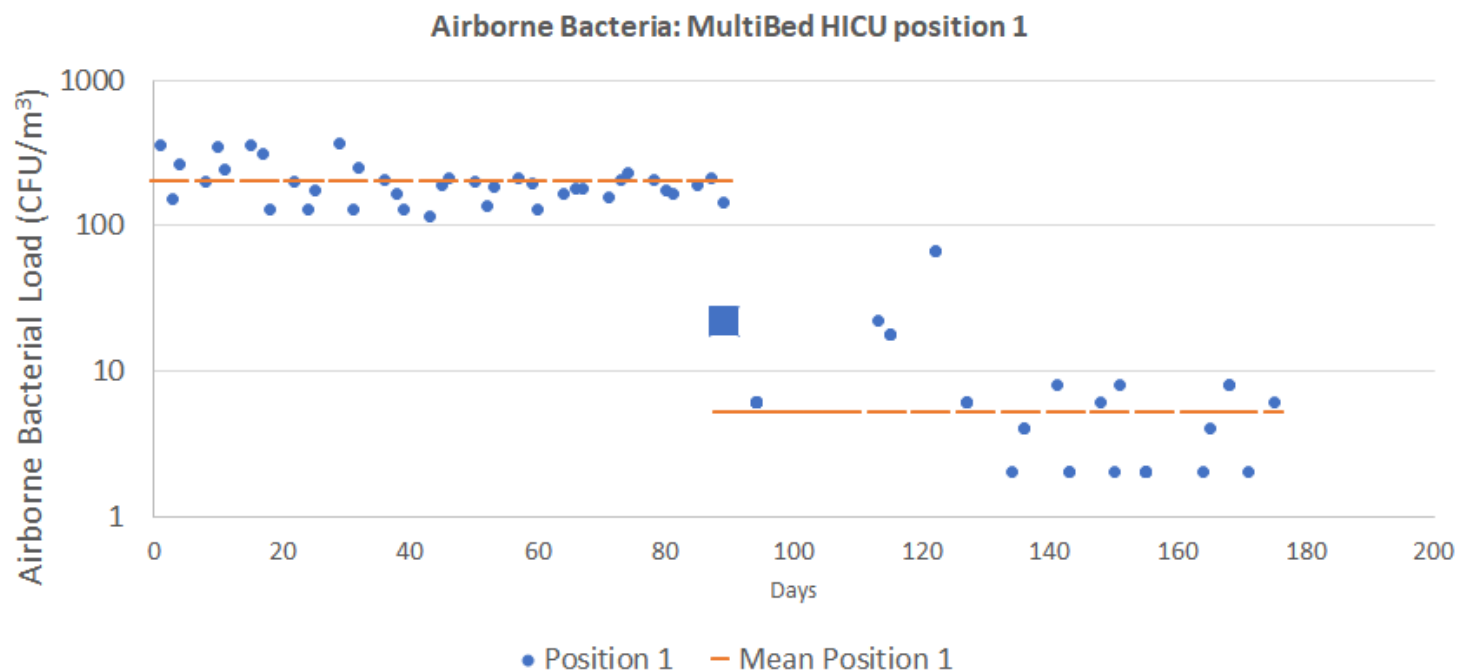

(b)

Airborne Bacteria: MultiBed HICU position 3

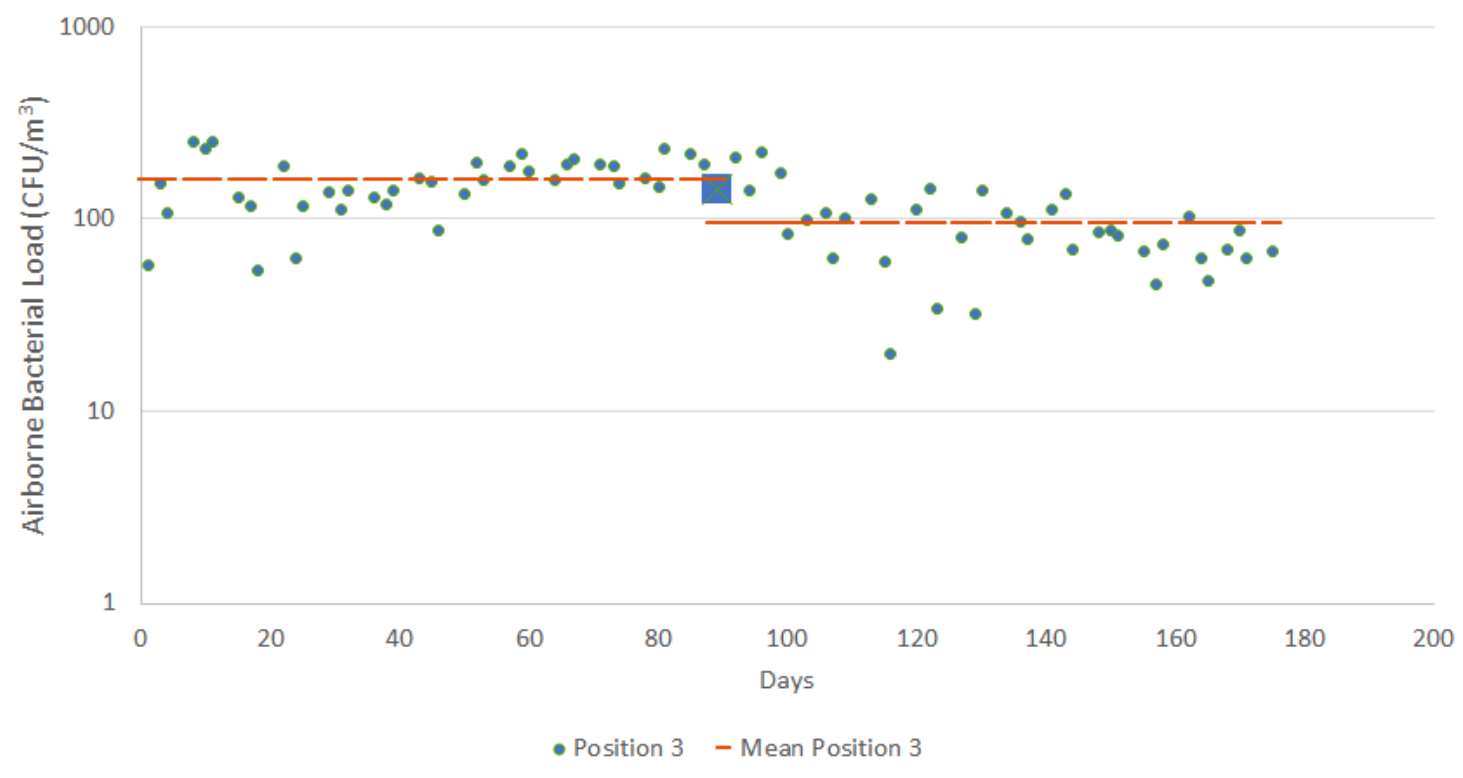

Figure 4: Airborne Bacterial load in Multi bed ICU. Active sampling was carried out from four positions. Positions 1 and 2 were 2 feet and 8 feet away, respectively, from the ZeBox technology powered air decontamination unit. Positions 3 and 4 were 25 feet and 26 feet away from the air decontamination unit. The ZeBox powered air decontamination unit was 
medRxiv preprint doi: https://doi.org/10.1101/2021.08.25.21262596; this version posted August 28, 2021. The copyright holder for this preprint (which was not certified by peer review) is the author/funder, who has granted medRxiv a license to display the preprint in perpetuity.

All rights reserved. No reuse allowed without permission.

(a)

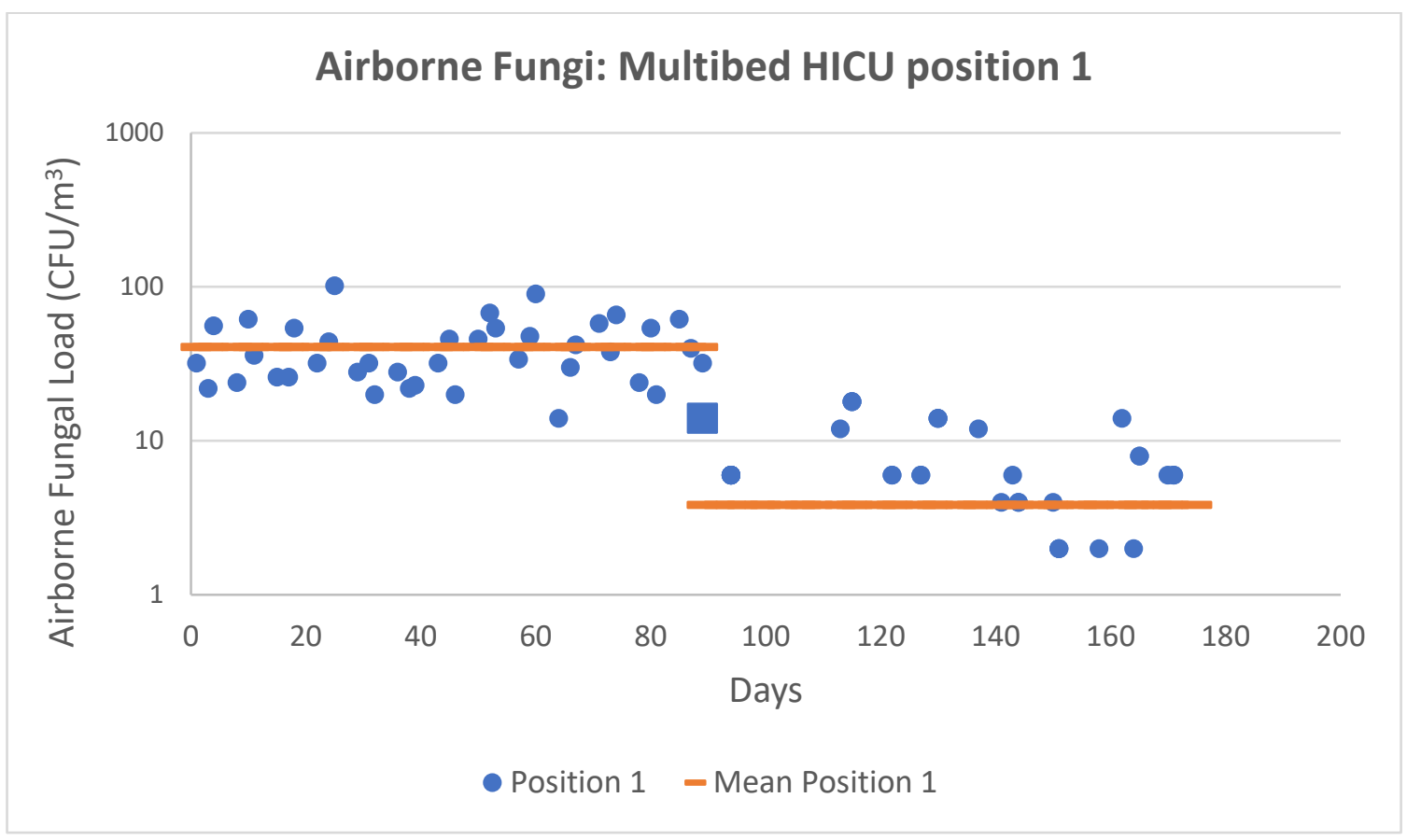

deployed on day 89 and the first sample was taken within 3 hours of deployment. The microbial count for that time point is depicted by a square. Graphs for positions 1 (Fig. 4a) and 3 (Fig. 4b) are shown here for comparison. Graphs for position 2 and 4 can be found in the supplementary material (Supplementary Figure 2A,2B). 


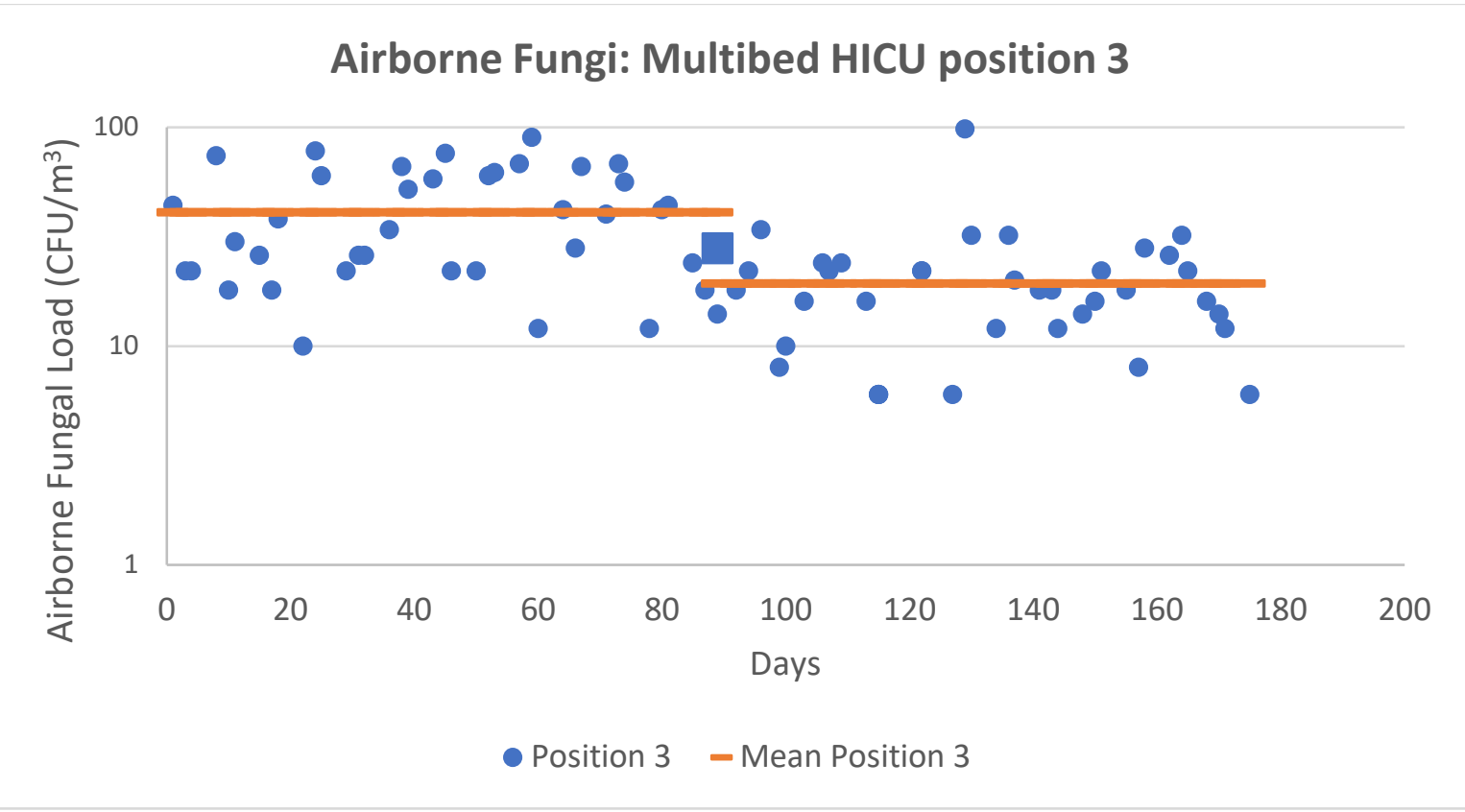

Figure 5: Assessment of Airborne fungal load in Multi bed ICU. Active sampling was carried out from four positions. Positions 1 and 2 were 2 feet and 8 feet away, respectively, from the ZeBox technology powered air decontamination unit. Positions 3 and 4 were 25 feet and 26 feet away from air decontamination unit. The ZeBox powered air decontamination unit was deployed on day 89 and the first sample was taken within 3 hours of deployment. The microbial count for that time point is depicted by a square. Graphs for positions 1 (Fig. 8 a) and 3 (Fig 8 b) are shown here for comparison. Graphs for position 2 and 4 can be found in the supplementary material.

\section{a) Surface microorganisms:}

The surface microbial load was monitored using techniques mentioned previously. Samples were collected from four different positions in the HICU room. Patient bed rails were selected as sampling locations. 
medRxiv preprint doi: https://doi.org/10.1101/2021.08.25.21262596; this version posted August 28, 2021. The copyright holder for this preprint (which was not certified by peer review) is the author/funder, who has granted medRxiv a license to display the preprint in perpetuity.

All rights reserved. No reuse allowed without permission.

Surface bacterial load before device deployment ranged from 6-620 CFU/ $\mathrm{cm}^{2}$ while the fungal load ranged from $0-70 \mathrm{CFU} / \mathrm{cm}^{2}$ across the four positions. After deployment of the decontamination device, the microbial load was reduced to $0-180 \mathrm{CFU} / \mathrm{cm}^{2}$ and $0-60$ $\mathrm{CFU} / \mathrm{cm}^{2}$ for bacterial and fungal population, respectively, across the four sampling positions. As before, the maximum reduction in surface bacterial load was shown at Position $1\left(0-34 \mathrm{CFU} / \mathrm{cm}^{2}\right)$ and Position $2\left(0-48 \mathrm{CFU} / \mathrm{cm}^{2}\right)$, which were 2 and 8 feet away from the device, while a lowered reduction was observed at Positions $3\left(2-120 \mathrm{CFU} / \mathrm{cm}^{2}\right)$ and Positions $4\left(2-180 \mathrm{CFU} / \mathrm{cm}^{2}\right)$, which were 24 and 26 feet away from the device. This accounted for a 78-90\% reduction in surface bacterial load at Positions 1 and 2, but only 62$67 \%$ reduction in surface bacterial load at Positions 3 and 4 . Similarly, the surface fungal load showed maximum reduction at Position $1\left(0-13 \mathrm{CFU} / \mathrm{cm}^{2}\right)$ and Position $2(0-10$ $\left.\mathrm{CFU} / \mathrm{cm}^{2}\right)$ and lower reductions at Position $3\left(0-60 \mathrm{CFU} / \mathrm{cm}^{2}\right)$ and Position $4(0-40$ $\mathrm{CFU} / \mathrm{cm}^{2}$ ). This accounted for $82-92 \%$ reduction of surface fungal load at Positions 1 and 2, and 37-50\% reduction in surface fungal load at Positions 3 and 4 (Supplementary Figure 03, Table 02).

\begin{tabular}{|c|c|c|c|c|c|c|c|c|c|}
\hline \multicolumn{2}{|c|}{} & \multicolumn{3}{|c|}{ Airborne Bacterial Load (CFU/m3) } & \multicolumn{3}{c|}{ Airborne Fungal Load (CFU/m3) } \\
\cline { 2 - 9 } & Position & Position & Position & Position & Position & Position & Position & Position \\
\hline $\begin{array}{c}\text { Pre- } \\
\text { Deployment }\end{array}$ & Range & 1 & 2 & 3 & 4 & 1 & 2 & 3 & 4 \\
\hline
\end{tabular}


medRxiv preprint doi: https://doi.org/10.1101/2021.08.25.21262596; this version posted August 28, 2021. The copyright holder for this preprint (which was not certified by peer review) is the author/funder, who has granted medRxiv a license to display the preprint in perpetuity.

All rights reserved. No reuse allowed without permission.

\begin{tabular}{|c|c|c|c|c|c|c|c|c|c|} 
& Mean & 203 & 176 & 159 & 185 & 41 & 46 & 41 & 36 \\
\hline & Median & 190 & 166 & 158 & 184 & 34 & 42 & 38 & 28 \\
\hline Post & Range & $0-66$ & $0-44$ & $20-210$ & $24-208$ & $0-18$ & $0-18$ & $0-98$ & $0-58$ \\
\hline & Mean & 5 & 7 & 96 & 103 & 4 & 3 & 19 & 18 \\
\hline & Median & 1 & 6 & 87 & 103 & 1 & 0 & 18 & 18 \\
& Reduction & 97 & 96 & 40 & 44 & 93 & 94 & 53 & 51 \\
\hline
\end{tabular}


medRxiv preprint doi: https://doi.org/10.1101/2021.08.25.21262596; this version posted August 28, 2021. The copyright holder for this preprint (which was not certified by peer review) is the author/funder, who has granted medRxiv a license to display the preprint in perpetuity.

All rights reserved. No reuse allowed without permission.

\begin{tabular}{|c|c|c|c|c|c|c|c|c|c|}
\hline & \multicolumn{4}{|c|}{ Surface Bacterial Load (CFU/cm2) } & \multicolumn{4}{|c|}{ Surface Fungal Load (CFU/cm2) } \\
\hline & & $\begin{array}{c}\text { Position } \\
1\end{array}$ & $\begin{array}{c}\text { Position } \\
2\end{array}$ & $\begin{array}{c}\text { Position } \\
3\end{array}$ & $\begin{array}{c}\text { Position } \\
4\end{array}$ & $\begin{array}{c}\text { Position } \\
1\end{array}$ & $\begin{array}{c}\text { Position } \\
2\end{array}$ & $\begin{array}{c}\text { Position } \\
3\end{array}$ & $\begin{array}{c}\text { Position } \\
4\end{array}$ \\
\hline \multirow{3}{*}{$\begin{array}{c}\text { Pre- } \\
\text { Deployment }\end{array}$} & Range & $6-520$ & $4-480$ & $6-520$ & $11-620$ & $0-50$ & $0-40$ & $0-70$ & $0-60$ \\
\hline & Mean & 96 & 69 & 111 & 139 & 21 & 17 & 22 & 24 \\
\hline & Median & 70 & 26 & 71 & 100 & 22 & 10 & 20 & 28 \\
\hline \multirow{4}{*}{$\begin{array}{c}\text { Post } \\
\text { Deployment }\end{array}$} & Range & $0-34$ & $0-48$ & $2-120$ & $2-180$ & $0-13$ & $0-10$ & $0-60$ & $0-40$ \\
\hline & Mean & 9 & 15 & 37 & 53 & 2 & 3 & 11 & 15 \\
\hline & Median & 9 & 13 & 22 & 40 & 0 & 2 & 8 & 12 \\
\hline & $\begin{array}{c}\% \\
\text { Reduction }\end{array}$ & 90 & 78 & 67 & 62 & 92 & 82 & 50 & 37 \\
\hline
\end{tabular}

Table 2: Descriptive statistics for airborne and surface microbial load in a multi bed ICU.

The airborne bacterial and fungal loads were measured at four positions. Position 1 and 2 were 2 feet and 8 feet away respectively while positions 3 and 4 were 25 feet and 26 feet away respectively from the decontamination device. 
medRxiv preprint doi: https://doi.org/10.1101/2021.08.25.21262596; this version posted August 28, 2021. The copyright holder for this preprint (which was not certified by peer review) is the author/funder, who has granted medRxiv a license to display the preprint in perpetuity.

All rights reserved. No reuse allowed without permission.

C. Microbial identification from Multi Bed Hospital ICU using $16 S$ rDNA sequencing

Following sequencing, alignment and taxonomical analysis on the sequenced genes, the organisms were identified and classified as pathogenic and non-pathogenic. As shown in Table 3, the pathogenic organisms identified were Bacillus cereus, Acinetobacter baumanii), Acinetobacter lwoffii (potentially opportunistic pathogen), Klebsiella pneumoniae, Brevundimonas sp. (rare case of opportunistic pathogen), Pseudomonas stutzeri (an opportunistic pathogen), Staphylococcus saprophyticus and Staphylococcus haemolyticus, hominis, cohnii (emerging opportunistic pathogens). In addition, over half a dozen non-pathogenic organisms were identified.

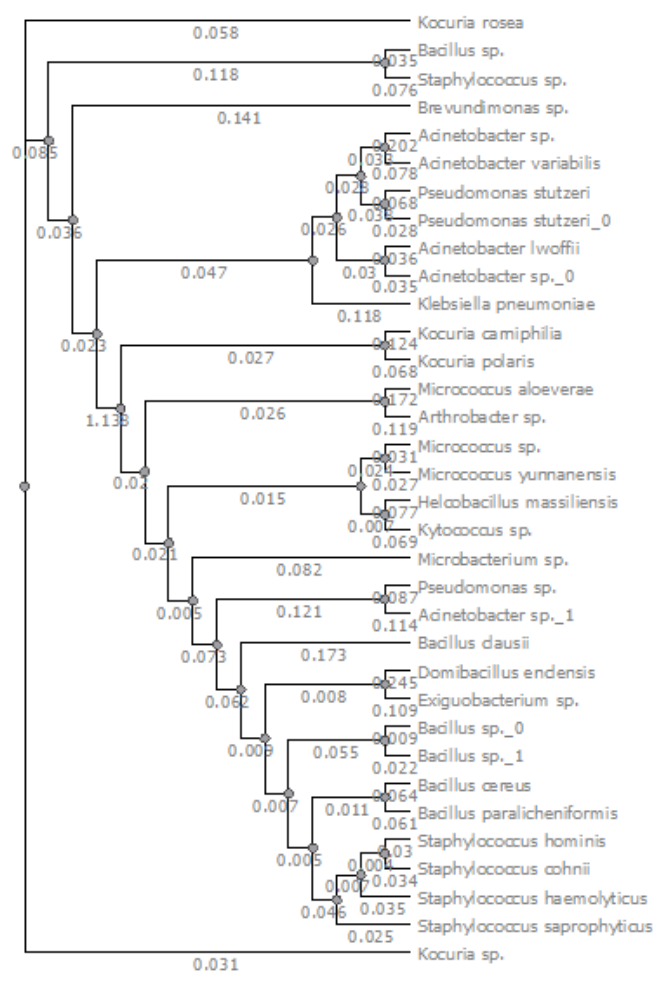

Figure 6: Phylogenetic tree of organisms isolated 
medRxiv preprint doi: https://doi.org/10.1101/2021.08.25.21262596; this version posted August 28, 2021. The copyright holder for this preprint (which was not certified by peer review) is the author/funder, who has granted medRxiv a license to display the preprint in perpetuity.

All rights reserved. No reuse allowed without permission.

The Minimum inhibitory concentration (MIC) of each of seven antibiotics was tested against each isolated organism. The seven antibiotics chosen represent current treatment choices across the various classes of available antibiotics. The sensitivity of the organisms to these antibiotics is tabulated in Table 3. Among the clinical isolates characterized, several

\begin{tabular}{|c|c|c|c|c|c|c|c|}
\hline Organism & \begin{tabular}{|l|} 
Ciprofloxacin \\
\end{tabular} & Meropenem & Ceftazidine & Azithromycin & Rifampicin & Ampicillin & Linezolid \\
\hline & & & & MIC $(\mu \mathrm{g} / \mathrm{ml})$ & & & \\
\hline \multicolumn{8}{|l|}{ Pathogenic } \\
\hline Acinetobacter sp. & 0.25 & 0.08 & 10 & 40 & 0.08 & 1.3 & 5 \\
\hline Acinetobacter Iwoffi & 0.25 & 0.08 & 10 & 40 & 0.08 & 1.25 & 5 \\
\hline Bacillus cereus & 0.06 & 0.08 & 10 & 40 & 0.08 & 2.5 & 1.3 \\
\hline Bacillus sp. & 0.06 & 0.08 & 10 & 40 & 0.08 & 2.5 & 1.3 \\
\hline Klebsiella pneumoniae & 0.02 & 0.04 & 0.15 & 0.3 & 0.63 & 0.15 & 0.15 \\
\hline Pseudomonas stutzeri & 0.02 & 0.04 & 0.15 & 0.3 & 0.63 & 0.15 & 0.2 \\
\hline Pseudomonas sp. & 0.06 & 0.08 & 10 & 40 & 0.08 & 2.5 & 1.3 \\
\hline Staphylococcus cohnii & 0.5 & 2.5 & 10 & 40 & 0.08 & 10 & 1.3 \\
\hline Staphylococcus haemolyticus & 0.5 & 0.31 & 10 & 40 & $<0.02$ & 0.3 & 2.5 \\
\hline Staphylococcus hominis & 0.5 & 0.31 & 10 & 40 & $<0.02$ & 0.3 & 2.5 \\
\hline Staphylococcus saprophyticus & 0.25 & 0.08 & 10 & 40 & 0.08 & 1.25 & 5 \\
\hline \multicolumn{8}{|l|}{ Non-Pathogenic / Opportunistic } \\
\hline Bacillus clausii & 0.06 & 0.08 & 10 & 40 & 0.08 & 2.5 & 1.3 \\
\hline Bacillus paralicheniformis & 0.06 & 0.08 & 10 & 40 & 0.08 & 2.5 & 1.3 \\
\hline Domibacillus enclensis & 0.06 & 0.08 & 10 & 40 & 0.08 & 2.5 & 1.3 \\
\hline Helcobacillus massiliensis & 0.06 & 0.08 & 10 & 40 & 0.08 & 2.5 & 1.3 \\
\hline Kocuria polaris & 0.02 & 0.04 & 0.15 & 0.3 & 0.63 & 0.15 & 0.15 \\
\hline Kytococcus sp. & 4 & 10 & 10 & 40 & 40 & 40 & 2.5 \\
\hline Micrococcus aloeverae & 4 & 10 & 10 & 40 & 40 & 40 & 2.5 \\
\hline Micrococcus yunnanensis & 4 & 10 & 10 & 40 & 40 & 40 & 2.5 \\
\hline Microbacterium sp. & 0.25 & 0.08 & 10 & 40 & 0.08 & 1.3 & 5 \\
\hline
\end{tabular}
$\operatorname{MIC}(\mu \mathrm{g} / \mathrm{ml})$. 
medRxiv preprint doi: https://doi.org/10.1101/2021.08.25.21262596; this version posted August 28, 2021. The copyright holder for this preprint (which was not certified by peer review) is the author/funder, who has granted medRxiv a license to display the preprint in perpetuity.

All rights reserved. No reuse allowed without permission.

\section{G. Statistical Analysis of Data}

Statistical analysis was carried out on the data set after leaving out the transition period, which was one day after turning on the ZeBox powered air decontamination unit when the microbial load should have settled into a new level of equilibrium. The Shapiro-Wilk test (SW test) indicated that except for some data at position S1 (medicine table) and post deployment bacterial load at position S2/S3 (nurse station/ bed rails) in the single bed ICU, most data sets were not normally distributed (data available in supplementary material). In the multi bed ICU, only the post deployment surface bacteria at Position 1 and airborne bacterial load at position 3 and post deployment airborne bacterial load at position 4 were normally distributed. The results from the $t$ test and the nonparametric "Mann-Whitney's U test" (MWU test) provided similar levels of confidence. Results of the t-test for all the cases are shown in Tables S4 and S5, and that of the MWU test in tables S6 and S7. We see that the reduction brought about by deployment of ZeBox technology powered air decontamination unit is significant in nearly all the cases, except for surface bacteria at position 2 in the single bed ICU and surface fungi at position 4 in the multibed ICU. All details are available in the Supplementary material.

\section{Discussion}

We carried out two independent studies to determine the efficiency of proprietary ZeBox technology powered air decontamination device in a single bed ICU and a multi bed ICU. Both studies were carried out when the rooms were occupied by patients, there was expected movement of hospital personnel and the hospital was fully functional. Devices underwent electrical safety and emission testing as per IEC60601-1-2 standards before deployment in 
medRxiv preprint doi: https://doi.org/10.1101/2021.08.25.21262596; this version posted August 28, 2021. The copyright holder for this preprint (which was not certified by peer review) is the author/funder, who has granted medRxiv a license to display the preprint in perpetuity.

All rights reserved. No reuse allowed without permission.

clinical environments. Over the sampling interval, the baseline cultures in indoor air showed considerable variation with large standard deviations but less standard deviation in certain locations as evidenced through surface swab samples. Such variations have been previously described in the literature [32].

The robust and reproducible effect of the ZeBox technology powered air decontamination unit was observed on indoor air and frequently touched surfaces by microbial culture. After 3 hours of deployment of the unit, upwards of $95 \%$ reduction of bacterial load and upwards of $85 \%$ reduction of fungal load was observed in indoor air in both single bed ICU and multibed HICUs, so long as the sampling locations were within the effective range of the device. Similar extent of reduction was observed in surface bacterial and fungal loads. We thus showed that air decontamination could substantially and simultaneously reduce the levels of surface deposition in the same setting irrespective of the type of pathogen present, viz bacteria, fungi and their spores.

In the multibed HICU study, at sites distal to the deployed unit, the reduction in airborne bacterial load ranged from $24-45 \%$ and airborne fungal load from $35-70 \%$. At the same distal sites, the surface bacterial load reduction ranged from $15-80 \%$ and fungal load reduction ranged from $61-73 \%$. At sites proximal to the ZeBox technology powered air decontamination unit, the reduction of both bacterial and fungal load was greater than $95 \%$. This indicates that a low bioburden zone was created with an approximate radius of 10-15 feet from the unit, for airborne bacterial and fungal load. These results are in concordance with the results obtained in earlier studies under controlled conditions [30].

To understand if the reduction in the microbial load post-deployment of ZeBox technology powered air decontamination unit was significant, we conducted a statistical analysis of the data (refer supplementary material for details). Since most statistical tests demand that the 
data be normally distributed, we first tested the data for normality using the Shapiro-Wilk test. We found that most of the datasets were not normally distributed. Therefore, to assess the significance of the reduction in microbial load due to ZeBox powered air decontamination unit, we conducted both a parametric test (Student's t-test) which is

which is applicable to non-normally distributed data. Despite the different assumptions and theoretical basis underlying the two tests, their conclusions were the same. Except for two cases of surface microbes, one on the bed rail in the single-bed ICU and another at a location farthest from the ZeBox technology powered air decontamination unit in the multi-bed ICU, the tests yielded $p$-values significantly less than 0.05 . This confirms that there was a significant reduction in the microbial load due to deployment of the ZeBox technology powered air decontamination unit.

Data on movement of people was not collected. Previously published studies linking occupancy of ICU to airborne culture numbers required intensive sampling over short time intervals which was not feasible in this study.

Several microbial strains resistant to Ceftazidine, Azithromycin and Ampicillin were found among the clinical isolates characterized. These are typical organisms found in hospital wards, some of which may be responsible for nosocomial or opportunistic infections in immunocompromised patients. The isolates were relatively more sensitive to the newer classes of antibiotics such as meropenem and linezolid. While most isolates were highly sensitive to Ciprofloxacin and Rifampicin, the latter is reserved as first line treatment for drug sensitive Tuberculosis, limiting its use against other infections. The Kytococcus and Micrococcus isolates which are resistant practically to all antibiotics tested except Linezolid would be expected to be particularly difficult to treat with available antibiotics, posing a challenge to infections in immunocompromised patients. Thus, an indoor environment 
equipped with an air decontamination unit which ideally eliminates microbes at source and provides near-sterile circulating air would be the desired way to prevent nosocomial infections.

Our study demonstrates that the innovative ZeBox technology can provide an effective trap and kill mechanism to eliminate a broad spectrum of airborne pathogens under clinical conditions. This in turn prevents re-settling of bacterial and fungal microorganisms on surfaces. Continuous operation of the ZeBox powered air decontamination unit can lead to ongoing reductions of pathogens in air and on environmental surfaces.

\section{Conclusion}

Effective decontamination technology that aids infection control in healthcare spaces must do the following:

1. kill pathogenic or contaminating microbes instead of merely trapping

2. operate continuously and safely in human presence

3. and require near-zero manual intervention while operating close to the source of infection or contamination.

No other technology being evaluated globally meets all these requirements. While filtration technologies fail to meet the first criterion, UV and ionization-based technologies fail to meet the last two. The unique, extremely effective, energy-efficient technology, ZeBox satisfies all these attributes. The devices powered by the proprietary ZeBox technology effectively eliminate airborne microorganisms like Staphylococcus aureus, Pseudomonas aeruginosa, Candida albicans, Aspergillus fumigatus spores, Mycobacterium smegmatis [30] and Mycobacterium tuberculosis, bacteriophages such as MS2 phage and Phi X 174 
$99.9999999 \%$ of viable microbial load based on the starting concentration under challenge conditions. In this study, we demonstrate that the ZeBox technology effectively eliminates the microbial population present in normally functioning hospital environments with efficiency over $95 \%$, from the air and close to $85 \%$ from high contact surfaces like patient bed rails. Reducing the environmental microbial load will reduce the occurrence of nosocomial infections in healthcare environments. Although this study demonstrates the device's capability in eliminating bacterial and fungal load from the environment, further study is required to assess impact on viruses under clinical settings, especially respiratory around immunocompromised patients, where the maintenance of low bioburden is critical to maintaining good health and preventing difficult to treat infections. 
medRxiv preprint doi: https://doi.org/10.1101/2021.08.25.21262596; this version posted August 28, 2021. The copyright holder for this preprint (which was not certified by peer review) is the author/funder, who has granted medRxiv a license to display the preprint in perpetuity.

All rights reserved. No reuse allowed without permission.

\section{Abbreviations}

\begin{tabular}{|l|l|}
\hline CDC & Centers for Disease Control and Prevention \\
\hline CFU & Colony Forming Units \\
\hline DNA & Deoxyribonucleic Acid \\
\hline DMSO & Dimethyl sulfoxide \\
\hline ESKAPE & $\begin{array}{l}\text { Enterococcus faecium, Staphylococcus aureus, } \\
\text { Klebsiella pneumoniae, Acinetobacter } \\
\text { baumannii, Pseudomonas aeruginosa, and } \\
\text { Enterobacter species }\end{array}$ \\
\hline HAI & Hospital Acquired Infection \\
\hline HBV & Hepatitis B Virus \\
\hline HICU & High Intensity Care Unit \\
\hline HSV & Herpes Simplex Virus \\
\hline HVAC & Heating, Ventilation and Air Conditioning \\
\hline ICU & Intensive Care Unit \\
\hline MDR & Multi-Drug Resistant \\
\hline MIC & Minimum Inhibitory Concentration \\
\hline MRSA & Methicillin Resistant Staphylococcus Aureus \\
\hline MWU test & Mann-Whitney's U test \\
\hline PBS & Phosphate-Buffered Saline \\
\hline PCR & Polymerase Chain Reaction \\
\hline rDNA & Recombinant DNA \\
\hline rRNA & Ribosomal ribonucleic acid \\
\hline SW test & Shapiro-Wilk test \\
\hline UV & Ultra Violet \\
\hline VRE & Vancomycin Resistant Enterococcus \\
\hline
\end{tabular}




\section{Funding:}

This work has been funded by Department of Biotechnology- Biotechnology Industry

Research Assistance Council (DBT-BIRAC), Government of India under Small Business

Innovation Research Initiative (SBIRI) [BT/SBIRI1372/31/16 and BT/SBIRI1557/36/18].

\section{Conflicts of Interest}

SN, SJ, SS, BK are employed with St John's Hospital and Medical College, Bangalore, Karnataka, India. SC,SB,IM are employed with Bangalore Baptist Hospital, Bangalore, Karnataka, India.DK, SP, DM, VN and AG are employed with Biomoneta Research Private Limited, India

\section{Declarations}

\section{A. Ethics approval and consent to participate:}

Institutional Ethics Committee approval were taken for this study. IEC Study Ref No 361/2017. for St John's Hospital and Medical College, Bangalore, Karnataka, India and

B. Consent for publication:

All authors read and approved the final submitted version. 
The datasets supporting the conclusions of this article are included within the article.

\section{Competing interests:}

\section{E. Funding:}

This work has been funded by Department of Biotechnology- Biotechnology Industry

Research Assistance Council (DBT-BIRAC), Government of India under Small Business Innovation Research Initiative (SBIRI) [BT/SBIRI1372/31/16 and BT/SBIRI1557/36/18].

\section{F. Authors' contributions:}

SN, SS, BK, SC and IM designed the experiments, SJ, SB and DK performed the experiments, SP, DM and VN performed statistical analysis. VN and AG wrote the initial manuscript. AG managed funding.

\section{G. Acknowledgments:}

Authors acknowledges the kind help of staff members of Department of Microbiology, St John's Hospital and Medical College, Bangalore, Karnataka, India and Department of Microbiology, Bangalore Baptist Hospital, Bangalore, Karnataka, India. We thank Dr. Santanu Datta and Dr.Janani Venkataraman for the constructive discussions on the manuscript. 
medRxiv preprint doi: https://doi.org/10.1101/2021.08.25.21262596; this version posted August 28, 2021. The copyright holder for this preprint (which was not certified by peer review) is the author/funder, who has granted medRxiv a license to display the preprint in perpetuity.

All rights reserved. No reuse allowed without permission. 
medRxiv preprint doi: https://doi.org/10.1101/2021.08.25.21262596; this version posted August 28, 2021. The copyright holder for this preprint (which was not certified by peer review) is the author/funder, who has granted medRxiv a license to display the preprint in perpetuity.

All rights reserved. No reuse allowed without permission.

\section{References}

1. Srikanth, P., S. Sudharsanam, and R. Steinberg. 2008. Bioaerosols in indoor environment: Composition, health effects and analysis. Indian J. Med. Microbiol. 26 (4): 302-312. doi:10.4103/0255-0857.43555.

3. Allegranzi B, Bagheri Nejad S, Combescure C, et al. Burden of endemic health-care associated infection in developing countries: systematic review and meta-analysis. Lancet. 2011;377(9761):228-241. doi:10.1016/S0140-6736(10)61458-4

4. Talon D. The role of the hospital environment in the epidemiology of multi-drug resistant bacteria. J Hosp Infect 1999;

$43: 13 \mathrm{e} 17$.

5. Nseir S, Blazejewski C, Lubret R, Wallet F, Courcol R, Durocher A. Risk of acquiring multidrug-resistant Gram-negative bacilli from prior room occupants in the intensive care unit. Clin Microbiol Infect. 2011;17(8):1201-1208. doi:10.1111/j.1469-

0691.2010.03420.x 
medRxiv preprint doi: https://doi.org/10.1101/2021.08.25.21262596; this version posted August 28, 2021. The copyright holder for this preprint (which was not certified by peer review) is the author/funder, who has granted medRxiv a license to display the preprint in perpetuity. All rights reserved. No reuse allowed without permission.

6. Estrada-Perez, C. E., J. P. Maestre, K. A. Kinney, M. D. King, and Y. A. Hassan. 2018. Droplet distribution and airborne bacteria in an experimental shower unit. WaterRes. 130:47-57. doi:10.1016/j.watres.2017.11.039.

7. Ferro, A. R., R. J. Kopperud, and L. M. Hildemann. 2004. Source strengths for indoor human activities that resuspend particulate matter. Environ. Sci. Technol. 38 (6): 17591764. doi:10.1021/es0263893.

8. Boor, B. E., J. A. Siegel, and A. Novoselac. 2013a. Monolayer and multilayer particle deposits on hard surfaces: Literature review and implications for particle resuspension in the indoor environment. Aeros. Sci. Technol.47 (8):831-847. doi:10.1080/02786826.2013.794928.

9. Mengjia Tang, Ningling Zhu, Kerry Kinney, and Atila Novoselac, Transport of indoor aerosols to hidden interior spaces, AEROSOL SCIENCE AND TECHNOLOGY, 2020, VOL. 54, NO. 1, 94-110 https://doi.org/10.1080/02786826.2019.1677854

10. Boor, B. E., J. A. Siegel, and A. Novoselac. 2013b. Wind tunnel study on aerodynamic particle resuspension from monolayer and multilayer deposits on linoleum flooring and galvanized sheet metal. Aeros. Sci. Technol. 47 (8): 848-857. doi:10.1080/02786826.2013.794929.

11. Kramer A, Schwebke I, Kampf G. How long do nosocomial pathogens persist on inanimate surfaces? A systematic review. BMC Infect Dis. 2006;6:130. Published 2006 Aug 16. doi:10.1186/1471-2334-6-130. 
medRxiv preprint doi: https://doi.org/10.1101/2021.08.25.21262596; this version posted August 28, 2021. The copyright holder for this preprint (which was not certified by peer review) is the author/funder, who has granted medRxiv a license to display the preprint in perpetuity.

All rights reserved. No reuse allowed without permission.

12. Marzoli F, Bortolami A, Pezzuto A, Mazzetto E, Piro R, Terregino C, Bonfante F, Belluco S. A systematic review of human coronaviruses survival on environmental surfaces. Sci Total Environ. 2021 Jul 15;778:146191. doi: 10.1016/j.scitotenv.2021.146191. Epub 2021 Mar 3. PMID: 33714096; PMCID: PMC7927581.

13. King, M., Noakes, C., Sleigh, P. and Camargo-Valero, M., 2013. Bioaerosol deposition in single and two-bed hospital rooms: A numerical and experimental study. Building and Environment, 59, pp.436-447.

14. Chemaly, Roy \& Simmons, Sarah \& Dale, Charles \& Ghantoji, Shashank \& Rodriguez, Maria \& Gubb, Julie \& Stachowiak, Julie \& Stibich, Mark. (2014). The role of the healthcare environment in the spread of multidrug-resistant organisms: update on current best practices for containment. Therapeutic advances in infectious disease. 2. 79-90. $10.1177 / 2049936114543287$.

15. Peterson, K., Novak, D., Stradtman, L., Wilson, D., \& Couzens, L. (2015). Hospital respiratory protection practices in 6 U.S. states: a public health evaluation study. American journal of infection control, 43(1), 63-71. doi: 10.1016/j.ajic.2014.10.008

16. Beltrami, E. M., Williams, I. T., Shapiro, C. N. \& Chamberland, M. E. 2000 Risk and management of blood-born infections in health care workers. Clin.Microbiol. Rev. 13, 385-407. (doi:10.1128/CMR.13.3.385-407.2000) 
medRxiv preprint doi: https://doi.org/10.1101/2021.08.25.21262596; this version posted August 28, 2021. The copyright holder for this preprint (which was not certified by peer review) is the author/funder, who has granted medRxiv a license to display the preprint in perpetuity.

All rights reserved. No reuse allowed without permission.

17. Centers for Disease Control and Prevention. Summary of Infection Prevention Practices in Dental Settings: Basic Expectations for Safe Care. Atlanta, GA: Centers for Disease Control and Prevention, US Dept of Health and Human Services; October 2016. Summary of Infection Prevention Practices in Dental Settings: Basic Expectations for Safe Care (cdc.gov) https://www.cdc.gov/oralhealth/infectioncontrol/pdf/safe-care2.pdf

18. Centers for Disease Control and Prevention 2003 Guidelines for environmental infection control in health-care facilities. Atlanta, GA: US Department of Health and Human Services, Public Health Service, Centers for Disease Control and Prevention. Guidelines for Environmental Infection Control in Health-Care Facilities: Recommendations of CDC and the Healthcare Infection Control Practices Advisory Committee (HICPAC) https://www.cdc.gov/mmwr/preview/mmwrhtml/rr5210a1.htm

19. Zemouri C, Awad SF, Volgenant CMC, Crielaard W, Laheij AMGA, de Soet JJ. Modelling of the Transmission of Coronaviruses, Measles Virus, Influenza Virus, Mycobacterium tuberculosis, and Legionella pneumophila in Dental Clinics. J Dent Res. 2020 Sep;99(10):1192-1198. doi: 10.1177/0022034520940288. Epub 2020 Jul 2. PMID: 32614681; PMCID: PMC7444020.

20. Prospero, E., Savini, S. \& Annino, I. 2003 Microbial aerosol contamination of dental healthcare workers' face and other surfaces in dental practice. Infect. Control Hosp.Epidemiol. 24, 139-141. (doi:10.1086/502172) 
medRxiv preprint doi: https://doi.org/10.1101/2021.08.25.21262596; this version posted August 28, 2021. The copyright holder for this preprint (which was not certified by peer review) is the author/funder, who has granted medRxiv a license to display the preprint in perpetuity.

All rights reserved. No reuse allowed without permission.

21. Mattos FF, Pordeus IA. COVID-19: a new turning point for dental practice. Braz Oral Res. 2020;34:e085. doi: 10.1590/1807-3107bor-2020.vol34.0085. Epub 2020 Jul 15. PMID: 32696908.

22. Naishadham Y, Jogishetty VK, Pacha VB, Balla SB, Vinay BH, Naishadham P. Quantification of Mycobacterium tuberculosis and Mycobacterium avium complex in human immunodeficiency virus-infected individuals with and without tuberculosis. J Oral Maxillofac Pathol. 2019 May-Aug;23(2):236-242. doi: 10.4103/jomfp.JOMFP_194_18. PMID: 31516230 ; PMCID: PMC6714263.

23. Mody L, Langa KM, Saint S, Bradley SF. Preventing infections in nursing homes: a survey of infection control practices in southeast Michigan. Am J Infect Control. 2005 Oct;33(8):489-92. doi: 10.1016/j.ajic.2005.01.011. PMID: 16216667; PMCID: PMC3319408

24. Maus R, Goppelsröder A, Umhauer H. Survival of bacterial and mold spores in air filter media. Atmospheric Environment. 2001256 Jan;35(1):105-13.

25. Boelter KJ, Davidson JH. Ozone generation by indoor, electrostatic air cleaners. Aerosol science and technology. 1997 Jan 1;27(6):689-708

26. Ghosh B, Lal H, Srivastava A. Review of bioaerosols in indoor environment with special reference to sampling, analysis and control mechanisms. Environment international. 2015 Dec;85:254-72. 
medRxiv preprint doi: https://doi.org/10.1101/2021.08.25.21262596; this version posted August 28, 2021. The copyright holder for this preprint (which was not certified by peer review) is the author/funder, who has granted medRxiv a license to display the preprint in perpetuity.

All rights reserved. No reuse allowed without permission.

27. Tang JW. The effect of environmental parameters on the survival of airborne infectious agents. Journal of the Royal Society Interface. 2009 Dec 6;6(suppl-6):S737-46.

28. Nardell EA, Bucher SJ, Brickner PW, Wang C, Vincent RL, Becan-McBride K, James MA, Michael M, Wright JD. Safety of upper-room ultraviolet germicidal air disinfection for room occupants: results from the Tuberculosis Ultraviolet Shelter Study. Public health reports. 2008 Jan;123(1):52-60.

29. Tang X, Feng F, Ye L, Zhang X, Huang Y, Liu Z, Yan K. Removal of dilute VOCs in air by post-plasma catalysis over Ag-based composite oxide catalysts. Catalysis today. 2013 Aug;211:39-43.

30. Kruttika S. Phadke, Deepak G. Madival, Janani Venkataraman, Debosmita Kundu, K. S. Ramanujan, Nisha Holla, Jaywant Arakeri, Gaurav Tomar, Santanu Datta, Arindam Ghatak. ZeBox: A novel non-intrusive continuous-use technology to trap and kill airborne microbes. bioRxiv 2021.08.02.454789

31. Wang Q, Garrity GM, Tiedje JM, Cole JR. Naive Bayesian classifier for rapid assignment of rRNA sequences into the new bacterial taxonomy. Applied and Environmental Microbiology. 2007;73:5261-5267. doi: 10.1128/AEM.00062-07.

32. O'Brien D, Stevens N, Fitzgerald-Hughes D, Humphreys H. Effect of a novel air disinfection system on airborne micro-organisms in a hospital outpatient clinic. J Hosp Infect. 2012 Jan;80(1):98-9. doi: 10.1016/j.jhin.2011.08.018. Epub 2011 Oct 20. PMID: 22018995. 
medRxiv preprint doi: https://doi.org/10.1101/2021.08.25.21262596; this version posted August 28, 2021. The copyright holder for this preprint (which was not certified by peer review) is the author/funder, who has granted medRxiv a license to display the preprint in perpetuity.

All rights reserved. No reuse allowed without permission. 
medRxiv preprint doi: https://doi.org/10.1101/2021.08.25.21262596; this version posted August 28, 2021. The copyright holder for this preprint (which was not certified by peer review) is the author/funder, who has granted medRxiv a license to display the preprint in perpetuity.

All rights reserved. No reuse allowed without permission.

\section{Supplementary material}

2

3

(a)

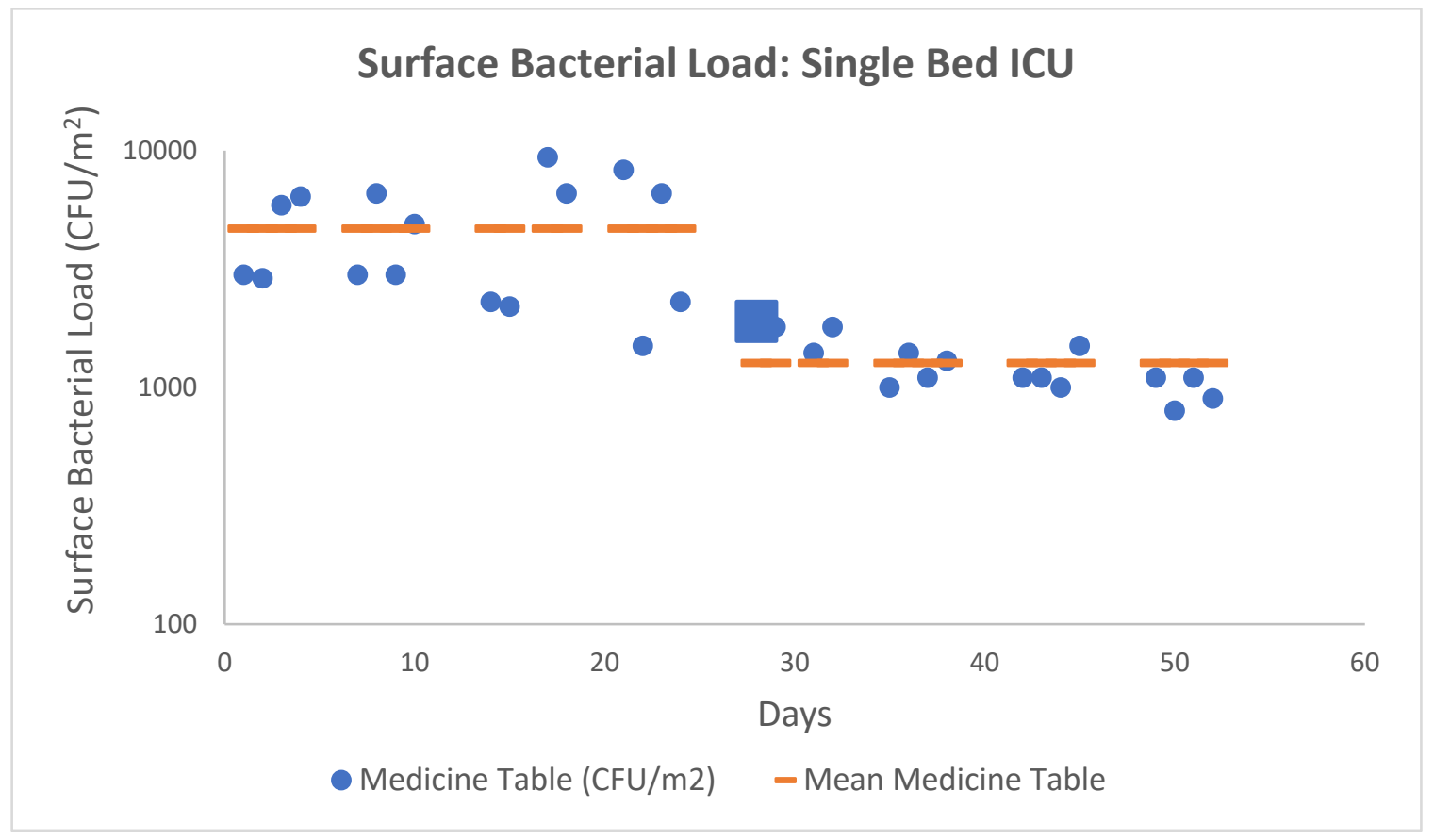

(b)

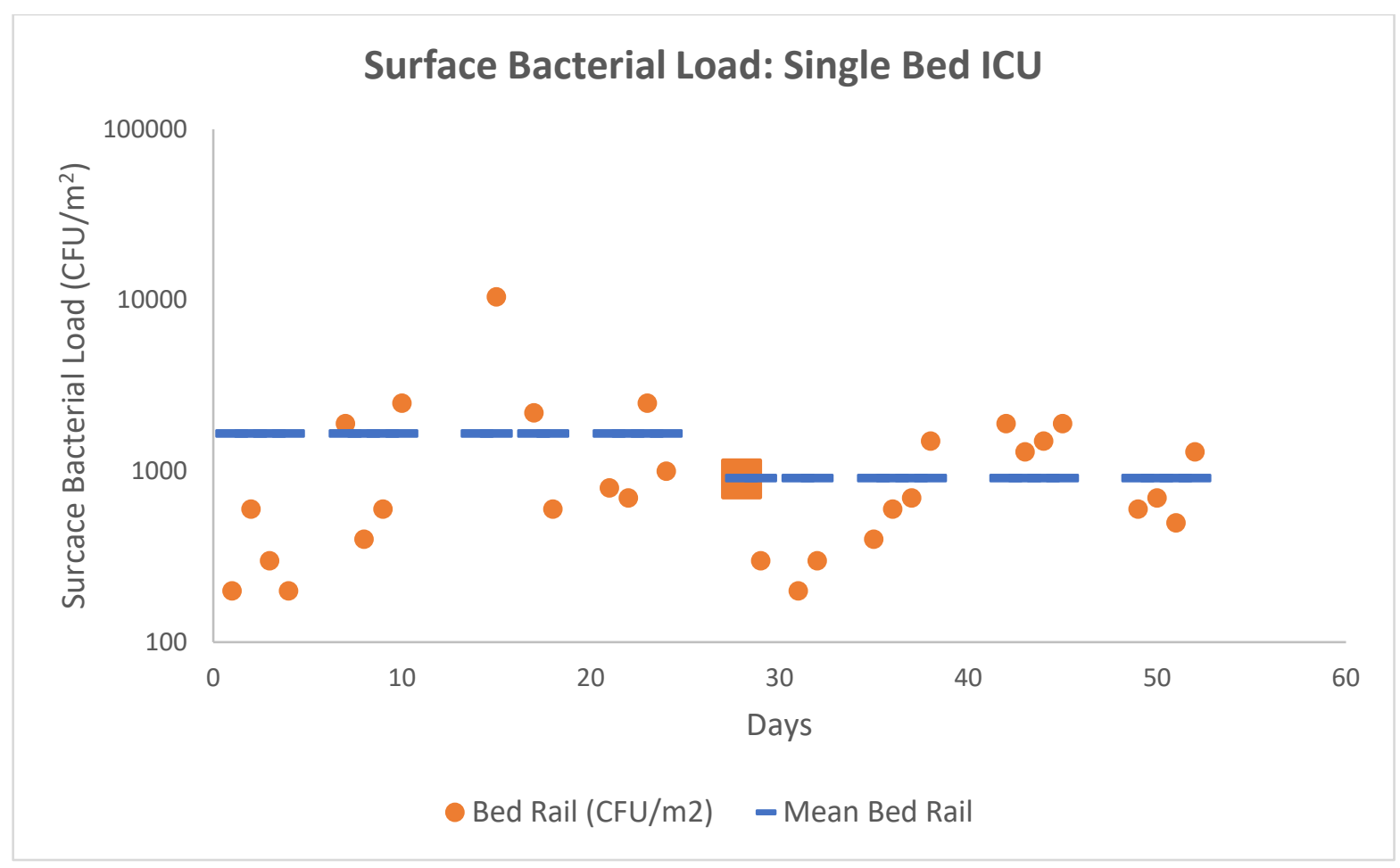


Supplementary Figure 1: Surface Bacterial Loads in a Single bed ICU at two positions.

(a) Position S1, Medicine table and (b) position S3, Bed rails. The average load before and after ZeBox deployment is depicted by a line for both positions. The ZeBox was deployed on day 28 and the first sample was taken within 3 hours of deployment. The microbial count for that time point is depicted by the square.

(a)

Surface Fungal Load: Single Bed ICU

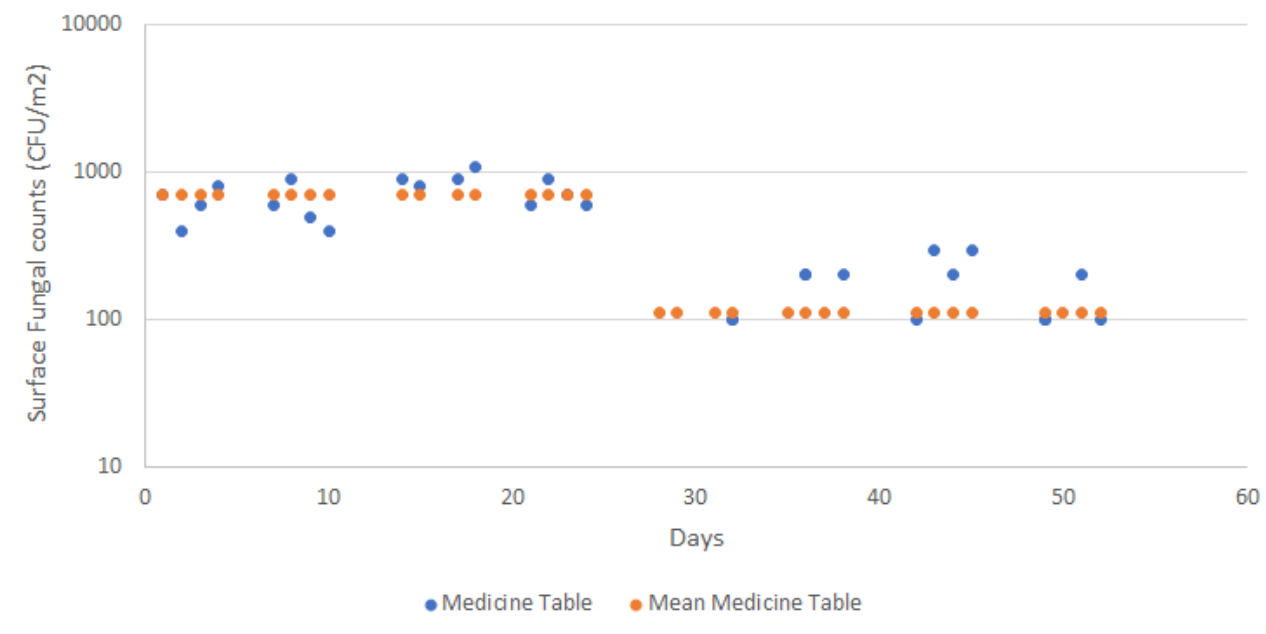

(b)

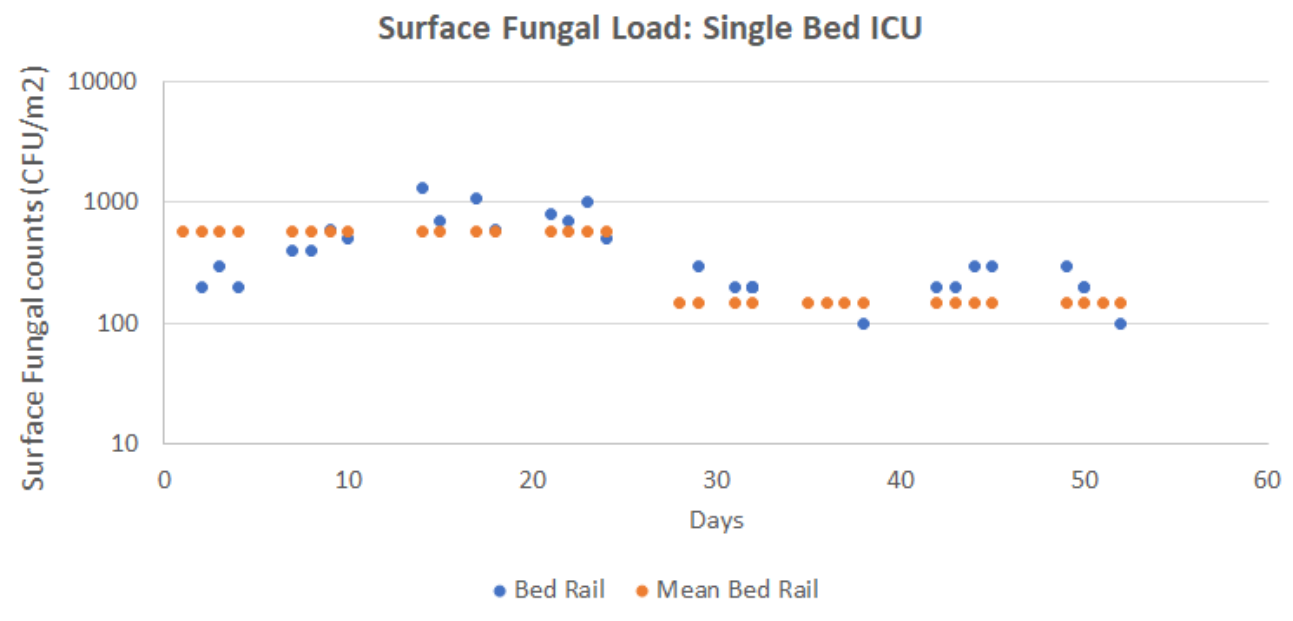


medRxiv preprint doi: https://doi.org/10.1101/2021.08.25.21262596; this version posted August 28, 2021. The copyright holder for this preprint (which was not certified by peer review) is the author/funder, who has granted medRxiv a license to display the preprint in perpetuity.

All rights reserved. No reuse allowed without permission.

Supplementary Figure 2: Surface Fungal Loads in a Single bed ICU at two positions.

(a) Position S1, Medicine table and (b) position S3, Bed rails. The average load before and after ZeBox deployment is depicted by a line for both positions. The ZeBox was deployed on day 28 and the first sample was taken within 3 hours of deployment. The microbial count for that time point was zero at both positions and is not shown here. 
medRxiv preprint doi: https://doi.org/10.1101/2021.08.25.21262596; this version posted August 28, 2021. The copyright holder for this preprint (which was not certified by peer review) is the author/funder, who has granted medRxiv a license to display the preprint in perpetuity.

All rights reserved. No reuse allowed without permission.

(a)

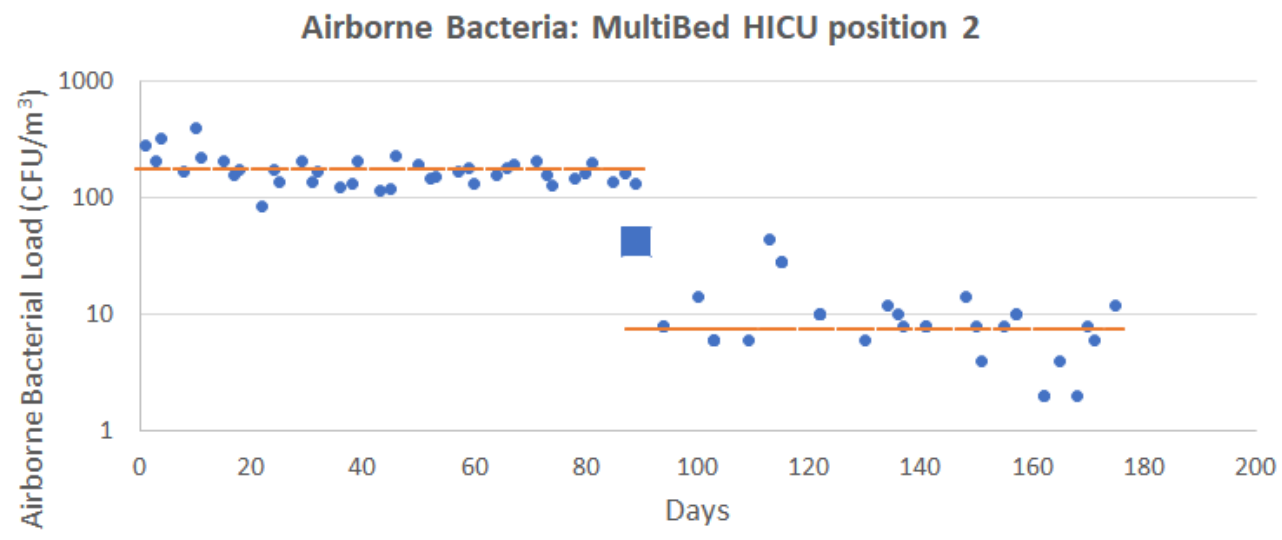

3

- Position $2-$ Mean Position 2

4

(b)

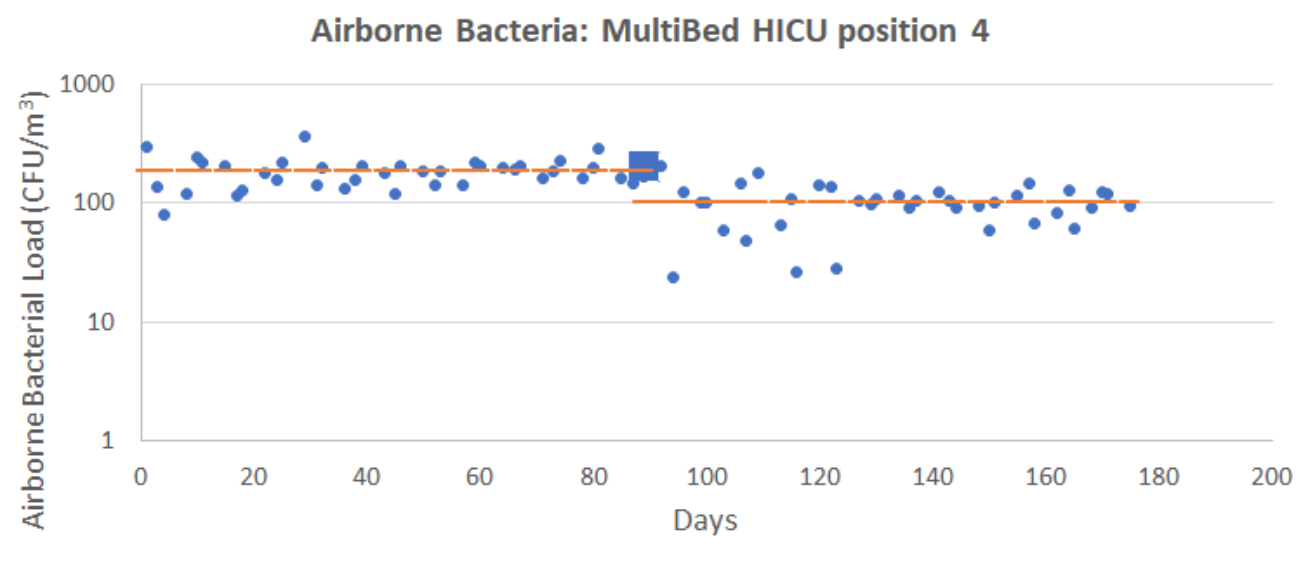

- Position 4 - Mean Position 4 
medRxiv preprint doi: https://doi.org/10.1101/2021.08.25.21262596; this version posted August 28, 2021. The copyright holder for this preprint (which was not certified by peer review) is the author/funder, who has granted medRxiv a license to display the preprint in perpetuity.

All rights reserved. No reuse allowed without permission.

1 Supplementary Figure 3: Airborne Bacterial load in Multi bed ICU. Active sampling was carried

2 out from four positions. Positions 2 (a) was 8 feet away, and Position 4 (b) was 26 feet away

3 from the ZeBox. The ZeBox was deployed on day 89 and the first sample was taken within 3

4 hours of deployment. The microbial count for that time point is depicted by a square. 
medRxiv preprint doi: https://doi.org/10.1101/2021.08.25.21262596; this version posted August 28, 2021. The copyright holder for this preprint (which was not certified by peer review) is the author/funder, who has granted medRxiv a license to display the preprint in perpetuity. All rights reserved. No reuse allowed without permission.

(a)

2

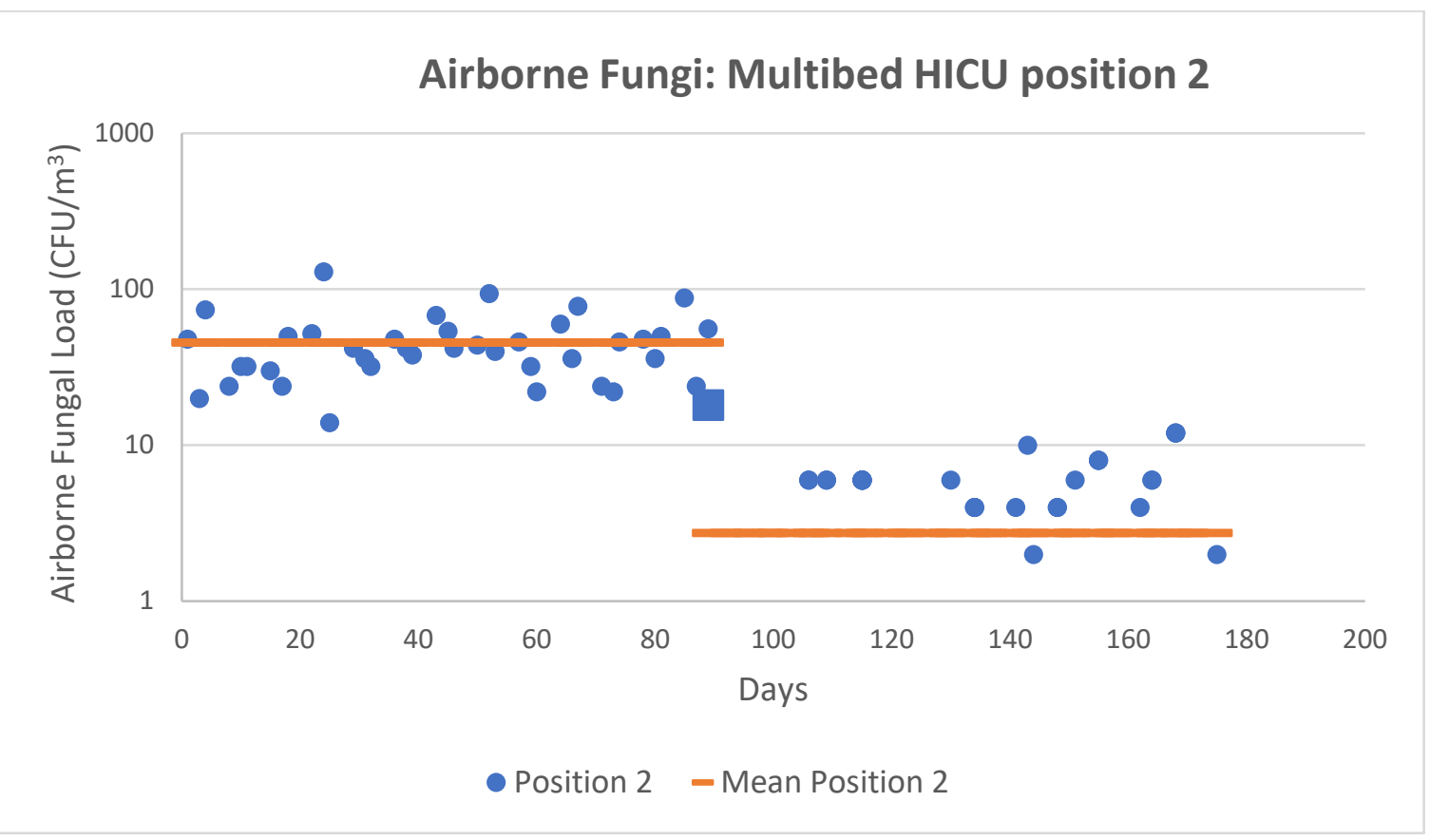

4

(b)

\section{Airborne Fungi: Multibed HICU position 4}

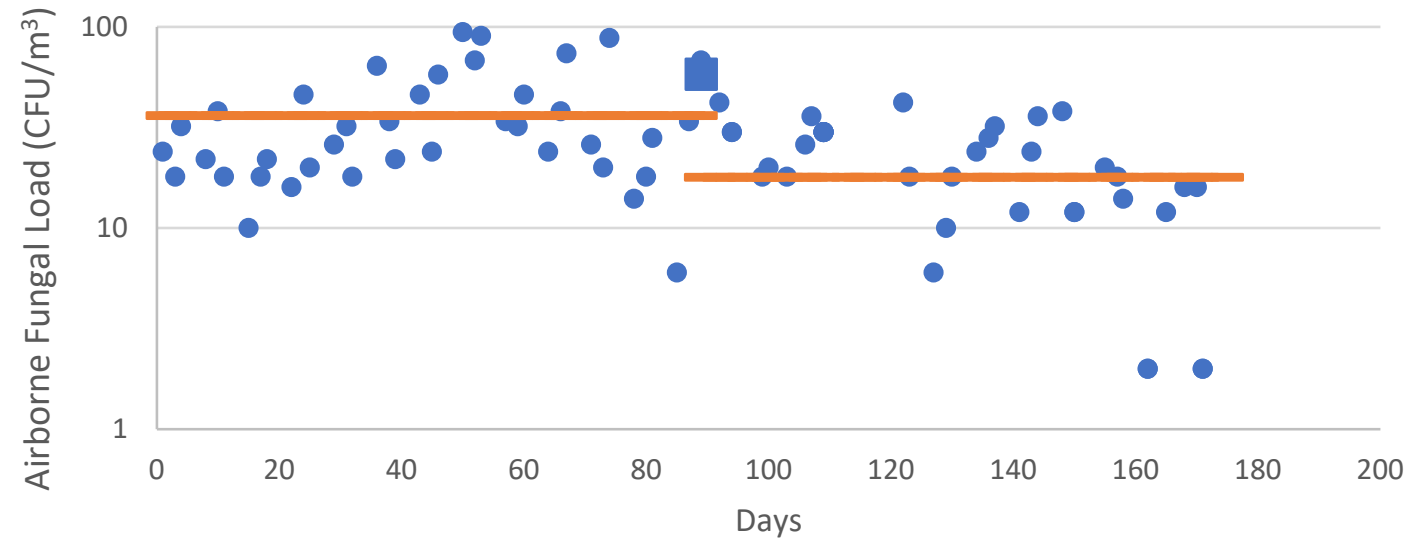

- Position 4 - Mean Position 4 
medRxiv preprint doi: https://doi.org/10.1101/2021.08.25.21262596; this version posted August 28, 2021. The copyright holder for this preprint (which was not certified by peer review) is the author/funder, who has granted medRxiv a license to display the preprint in perpetuity.

All rights reserved. No reuse allowed without permission.

2 Supplementary Figure 4: Airborne Fungal load in Multi bed ICU. Active sampling was carried

3 out from four positions. Positions 2 (a) was 8 feet away, and Position 4(b) was 26 feet away from

4 the ZeBox. The ZeBox was deployed on day 89 and the first sample was taken within 3 hours of

5 deployment. The microbial count for that time point is depicted by a square. 
medRxiv preprint doi: https://doi.org/10.1101/2021.08.25.21262596; this version posted August 28, 2021. The copyright holder for this preprint (which was not certified by peer review) is the author/funder, who has granted medRxiv a license to display the preprint in perpetuity.

All rights reserved. No reuse allowed without permission.

(a)

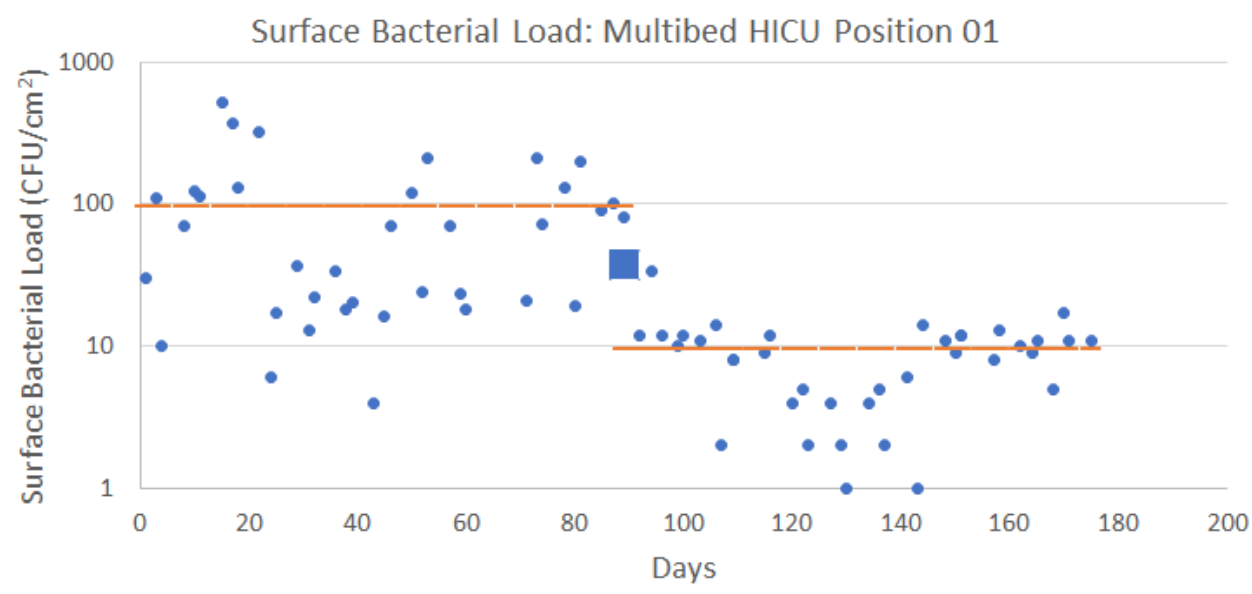

2

- Position 1 - Mean Position 1

3 (b)

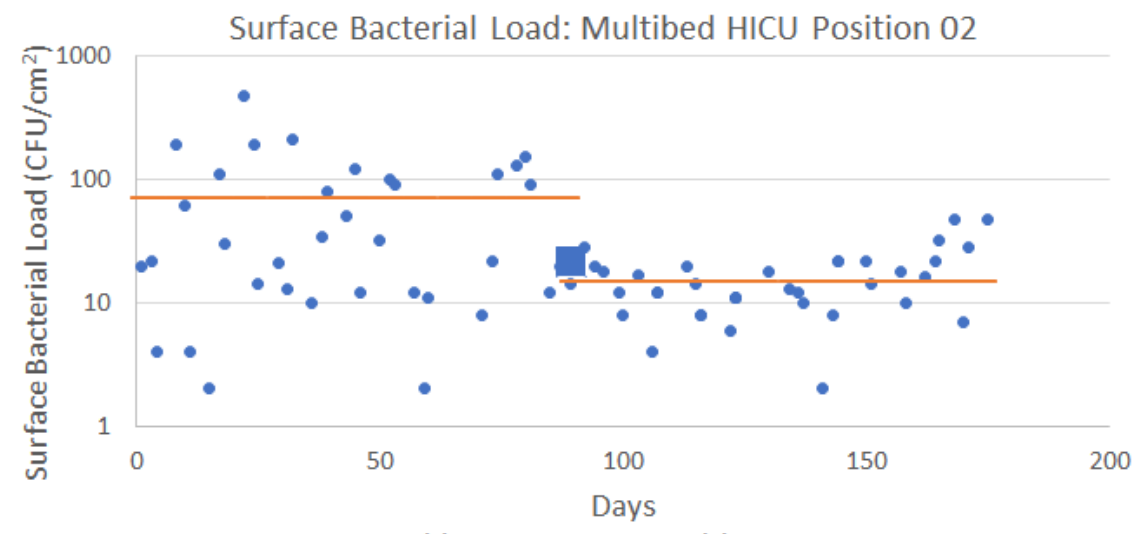

- Position 2 - Mean Position 2

(c)

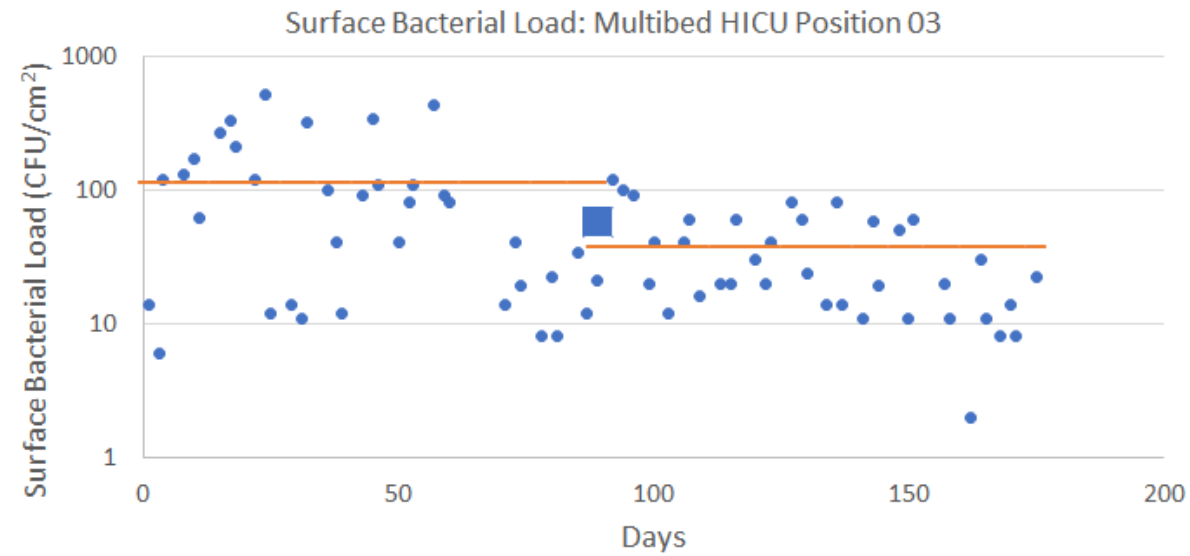

- Position 3 - Mean Position 3 


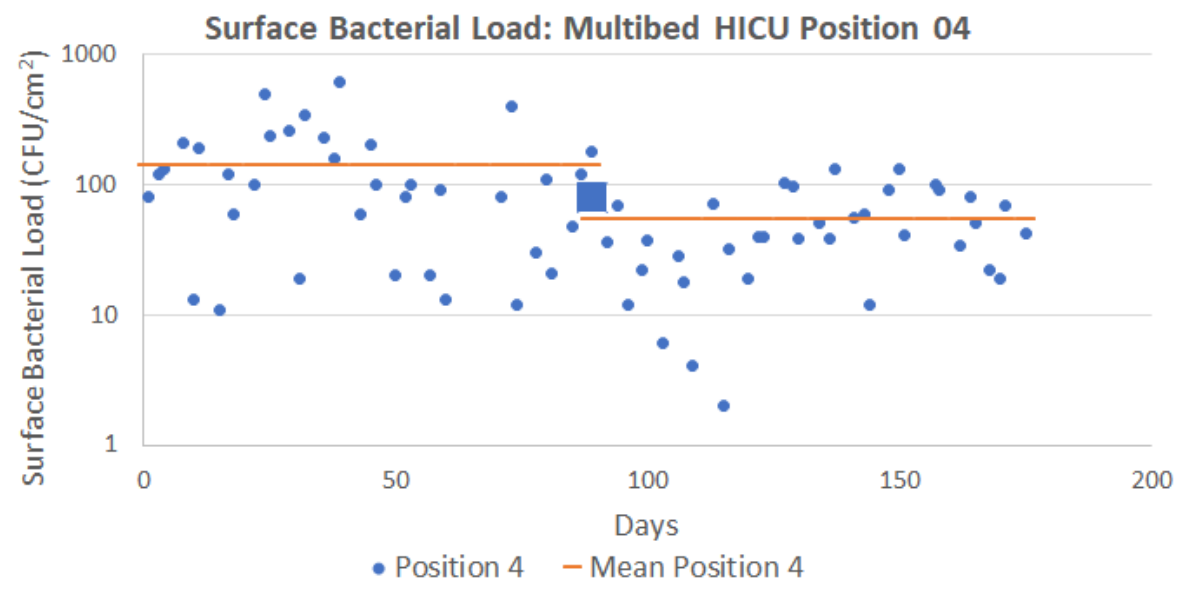

6 Supplementary Figure 5: Surface Bacterial load in Multi bed ICU. Positions 1 and 2 were 2 feet

7 and 8 feet away, respectively, from the ZeBox. Positions 3 (a) and 4 (b) were 25 feet and 26 feet

8 away from the ZeBox. The ZeBox was deployed on day 89 and the first sample was taken within

93 hours of deployment. The microbial count for that time point is depicted by a square. 
medRxiv preprint doi: https://doi.org/10.1101/2021.08.25.21262596; this version posted August 28, 2021. The copyright holder for this preprint (which was not certified by peer review) is the author/funder, who has granted medRxiv a license to display the preprint in perpetuity.

All rights reserved. No reuse allowed without permission.

(a)

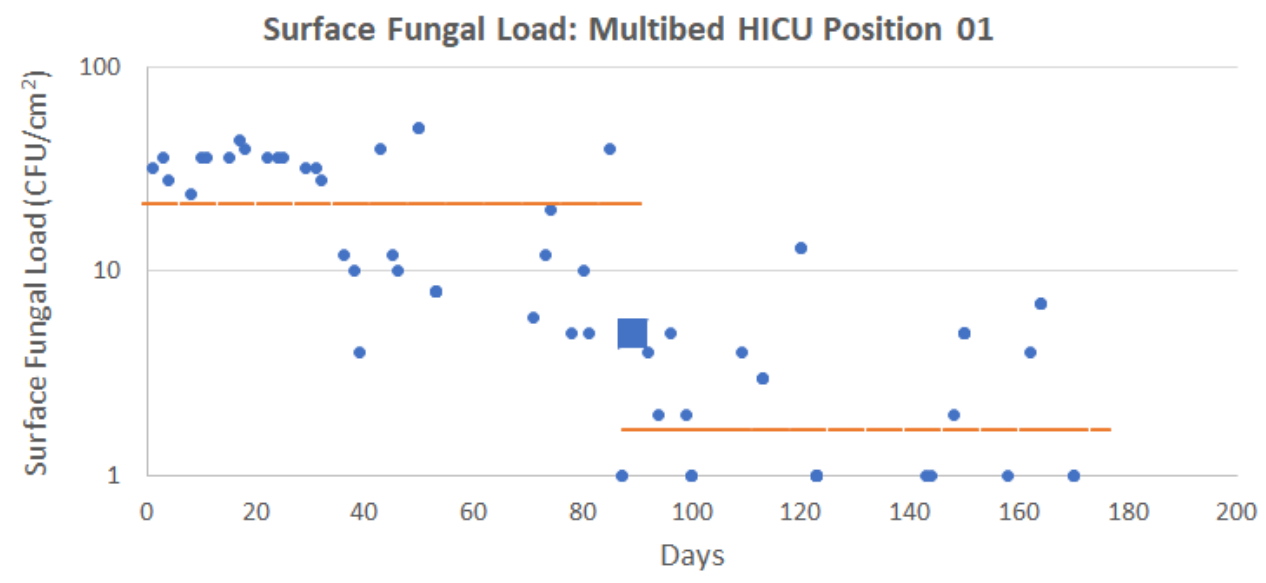

2

- Position 1 - Mean Position 1

3 (b)

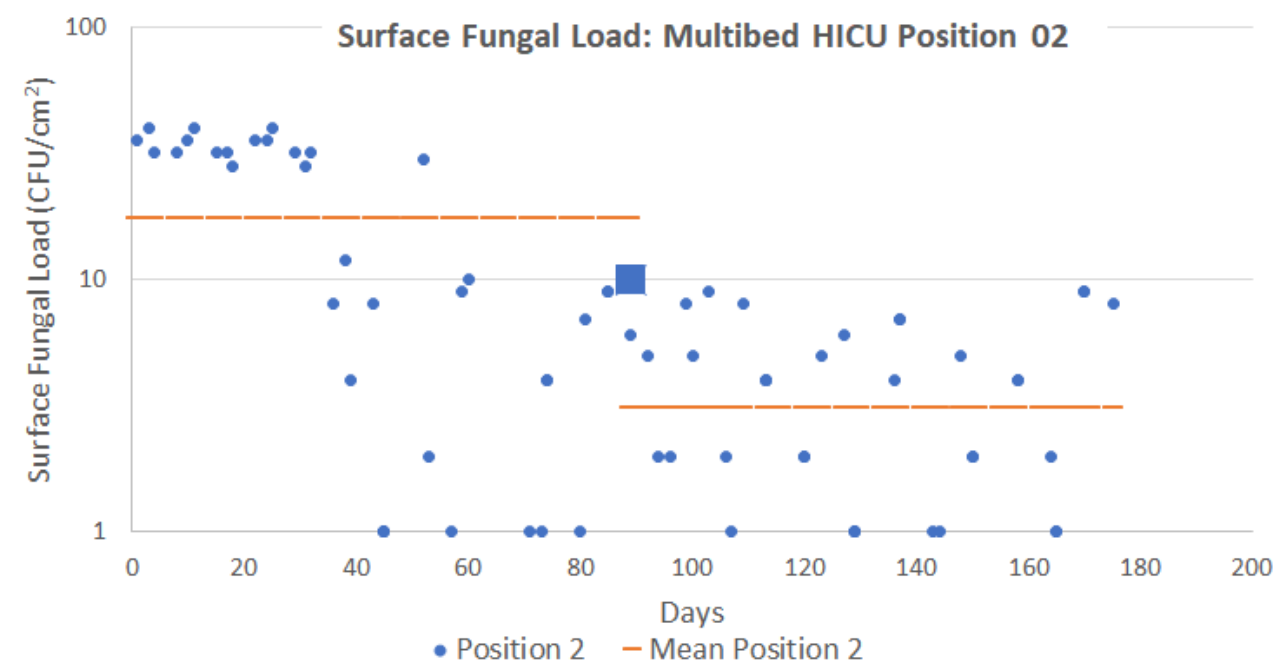

(c)

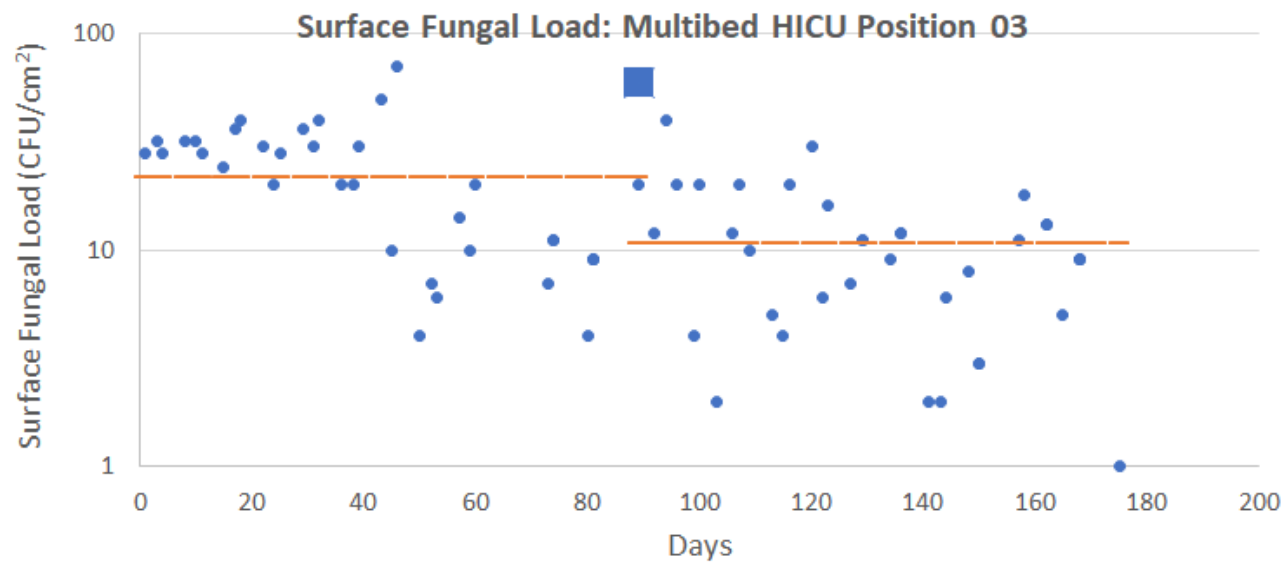


(d)

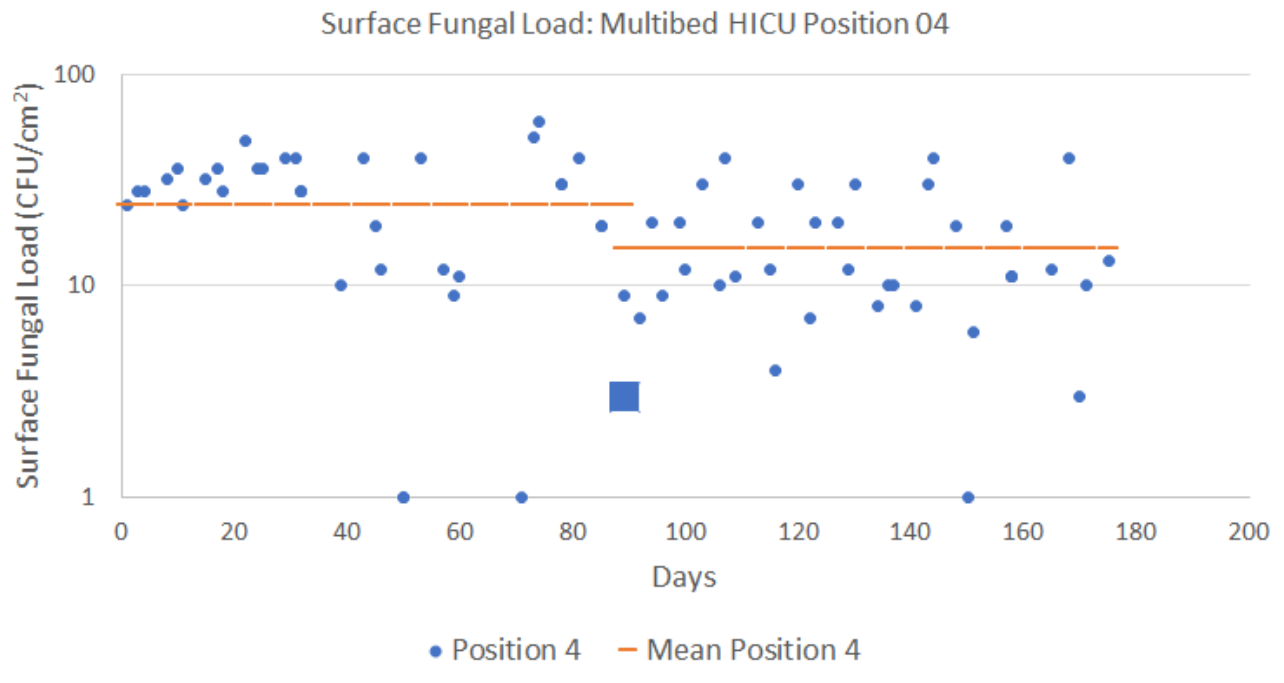

Figure S4: Surface Fungal load in Multi bed ICU. Positions 1(a) and 2 (b) were 2 feet and 8 feet away, respectively, from the ZeBox. Positions 3 (c) and 4 (d) were 25 feet and 26 feet away from the ZeBox. The ZeBox was deployed on day 89 and the first sample was taken within 3 hours of deployment. The microbial count for that time point is depicted by a square. 
medRxiv preprint doi: https://doi.org/10.1101/2021.08.25.21262596; this version posted August 28, 2021. The copyright holder for this preprint (which was not certified by peer review) is the author/funder, who has granted medRxiv a license to display the preprint in perpetuity.

All rights reserved. No reuse allowed without permission.

\section{Statistical analysis of data}

Statistical tests were used to determine the significance of the reduction in microbial load due to ZeBox. We divide the time series of measured microbial load into pre-deployment and postdeployment periods. After turning on ZeBox, there is a finite period of transition until the microbial load settles to a new (lower) equilibrium level. The post-deployment period was reckoned to begin at the end of the transition period, assumed to be 1 day after turning on ZeBox.

Most statistical tests applicable to our case make two major assumptions: (1) The data in the preand post-deployment periods are statistically steady (or stationary); this implies that the statistics of the microbial load within a given period does not change progressively over time, and (2) The data is sampled from a normal (or, Gaussian) distribution. The first assumption is valid because we have left out the transition period from consideration. Whether the second assumption is valid was determined by testing the data for normality using Shapiro-Wilk test (SW test). The null hypothesis for the SW test is that the dataset is sampled from a normal distribution. Table S1 and Table S2 show the results of the SW test; each entry is a pair of the SW-statistic and the corresponding p-value. All the statistical tests were done using the scipy-statistics package in python. The cases with $\mathrm{p}$-value $>0.05$, marked in green, indicate that the corresponding datasets are indeed sampled from a normal distribution. We see that most datasets are in fact not sampled from a normal distribution.

\begin{tabular}{|l|l|l|l|l|}
\hline \multirow{2}{*}{ SW test, Single } & \multicolumn{2}{|c|}{ Position 1 } & \multicolumn{2}{c|}{ Position 2 } \\
\cline { 2 - 5 } & Pre-deployment & Post-deployment & Pre-deployment & Post-deployment \\
\hline Airborne bacteria & $0.82,<0.001$ & $0.96,0.20$ & $0.94,0.026$ & $0.98,0.64$ \\
\hline
\end{tabular}


medRxiv preprint doi: https://doi.org/10.1101/2021.08.25.21262596; this version posted August 28, 2021. The copyright holder for this preprint (which was not certified by peer review) is the author/funder, who has granted medRxiv a license to display the preprint in perpetuity. All rights reserved. No reuse allowed without permission.

\begin{tabular}{|l|l|l|l|l|} 
Airborne fungi & $0.59,<0.001$ & $0.75,<0.001$ & $0.66,0.75,<0.001$ & $0.72,0.75,<0.001$ \\
\hline Surface bacteria & $0.90,0.079$ & $0.90,0.13$ & $0.46,0.75,<0.001$ & $0.97,0.91$ \\
\hline Surface fungi & $0.95,0.47$ & $0.90,0.12$ & $0.89,0.092$ & $0.85,0.031$ \\
\hline
\end{tabular}

Table S1. SW test for single bed ICU data. Each entry is a pair of SW-statistic and the corresponding p-value.

\begin{tabular}{|l|l|l|l|l|}
\hline \multirow{2}{*}{ SWed ICU } & \multicolumn{2}{|c|}{ Position 1 } & \multicolumn{2}{c|}{ Position 2} \\
\cline { 2 - 5 } & Pre-deployment & Post-deployment & Pre-deployment & Post-deployment \\
\hline Airborne bacteria & $0.87,<0.001$ & $0.43,<0.001$ & $0.81,<0.001$ & $0.70,<0.001$ \\
\hline Airborne fungi & $0.90,0.003$ & $0.75,<0.001$ & $0.87,<0.001$ & $0.75,<0.001$ \\
\hline Surface bacteria & $0.74,<0.001$ & $0.95,0.12$ & $0.69,<0.001$ & $0.87,0.0012$ \\
\hline Surface fungi & $0.88,0.0013$ & $0.58,<0.001$ & $0.83,<0.001$ & $0.83,<0.001$ \\
\hline
\end{tabular}

\begin{tabular}{|l|l|l|l|l|}
\hline \multirow{2}{*}{ SWed ICU } & \multicolumn{2}{|c|}{ Position 3 } & \multicolumn{2}{c|}{ Position 4} \\
\cline { 2 - 5 } & Pre-deployment & Post-deployment & Pre-deployment & Post-deployment \\
\hline Airborne bacteria & $0.98,0.87$ & $0.94,0.052$ & $0.92,0.007$ & $0.97,0.59$ \\
\hline Airborne fungi & $0.92,0.012$ & $0.70,<0.001$ & $0.86,<0.001$ & $0.92,0.02$ \\
\hline Surface bacteria & $0.78,<0.001$ & $0.87,<0.001$ & $0.81,<0.001$ & $0.93,0.03$ \\
\hline Surface fungi & $0.94,0.037$ & $0.90,0.0049$ & $0.93,0.023$ & $0.90,0.0065$ \\
\hline
\end{tabular}
value. 
medRxiv preprint doi: https://doi.org/10.1101/2021.08.25.21262596; this version posted August 28, 2021. The copyright holder for this preprint (which was not certified by peer review) is the author/funder, who has granted medRxiv a license to display the preprint in perpetuity.

All rights reserved. No reuse allowed without permission.

1 If pre- and post-deployment datasets are both normally distributed then, to assess the

2 significance of the reduction in microbial load post-deployment of ZeBox, we may use a

3 parametric test such as the "two sample, left tailed t-test", otherwise a non-parametric test such as

4 the "Mann-Whitney's U test" (MWU test) is appropriate [1]. For the t-test, the null hypothesis is

5 that the mean microbial load in pre- and post-deployment periods are the same, and the alternative

6 hypothesis is that the ZeBox brings about a reduction in the mean microbial load (which therefore

7 requires a left-sided test). For the MWU test, the null hypothesis is that the pre- and post-

8 deployment datasets are sampled from the same probability distribution, while the alternative

9 hypothesis is that they are sampled from different distributions and that the ZeBox brings about a

10 reduction in the microbial load (which therefore requires a left-sided test).

11 Results of the t-test for all the cases are shown in tables S3 and S4, and that of the MWU test in

12 tables S5 and S6. We see that the reduction brought about by deployment of ZeBox is significant

13 in nearly all the cases, except for surface bacteria at position 2 in the single bed ICU and surface

14 fungi at position 4 in the multi bed ICU

\begin{tabular}{|l|l|c|}
\hline t-test, Single Bed & Position 1 & Position 2 \\
\hline Airborne bacteria & $14.4,<0.001$ & $14.4,<0.001$ \\
\hline Airborne fungi & $6.8,<0.001$ & $6.9,<0.001$ \\
\hline Surface bacteria & $5.1,<0.001$ & $1.2,0.13$ \\
\hline Surface fungi & $9.3,<0.001$ & $4.3,<0.001$ \\
\hline
\end{tabular}

Table S3. Two sample, left-sided t-test for single bed data. Each entry is a pair of t-statistic and the corresponding p-value. 
medRxiv preprint doi: https://doi.org/10.1101/2021.08.25.21262596; this version posted August 28, 2021. The copyright holder for this preprint (which was not certified by peer review) is the author/funder, who has granted medRxiv a license to display the preprint in perpetuity.

All rights reserved. No reuse allowed without permission.

\begin{tabular}{|l|l|l|l|l|}
\hline I-test, Multi Bed & Position 1 & Position 2 & Position 3 & Position 4 \\
\hline ICU & & & & \\
\hline Airborne bacteria & $17.8,<0.001$ & $17.6,<0.001$ & $6.9,<0.001$ & $8.0,<0.001$ \\
\hline Surface bacteria & $4.5,<0.001$ & $3.4,<0.001$ & $3.6,<0.001$ & $3.6,<0.001$ \\
\hline Surface fungi & $6.7,<0.001$ & $5.1,<0.001$ & $4.5,<0.001$ & $2.1,0.02$ \\
\hline
\end{tabular}

Table S4. Two sample, left-sided t-test for multi bed data. Each entry is a pair of t-statistic and the corresponding p-value.

\begin{tabular}{|l|c|c|}
\hline MWU-test, Single & Position 1 & Position 2 \\
Bed ICU & & \\
\hline Airborne bacteria & $1591,<0.001$ & $1570,<0.001$ \\
\hline Airborne fungi & $1580,<0.001$ & $1541,<0.001$ \\
\hline Surface bacteria & $207,<0.001$ & $111,0.39$ \\
\hline Surface fungi & $208,<0.001$ & $186,<0.001$ \\
\hline
\end{tabular}

Table S5. Two sample, left-sided MWU-test for single bed data. Each entry is a pair of MWUstatistic and the corresponding p-value.

\begin{tabular}{|l|c|c|c|c|}
\hline MWU-test, Multi & Position 1 & Position 2 & Position 3 & Position 4 \\
Bed ICU & & & & \\
\hline Airborne bacteria & $1330,<0.001$ & $1330,<0.001$ & $1170,<0.001$ & $1240,<0.001$ \\
\hline
\end{tabular}


medRxiv preprint doi: https://doi.org/10.1101/2021.08.25.21262596; this version posted August 28, 2021. The copyright holder for this preprint (which was not certified by peer review) is the author/funder, who has granted medRxiv a license to display the preprint in perpetuity.

All rights reserved. No reuse allowed without permission.

1 Table S6. Two sample, left-sided MWU-test for multi bed data. Each entry is a pair of MWU-

2 statistic and the corresponding p-value.

3

4 References

5

6 [1] Rochon J, Gondan M, Kieser M. To test or not to test: Preliminary assessment of normality

7 when comparing two independent samples. BMC medical research methodology. 2012

8 Dec;12(1):1-1. 
medRxiv preprint doi: https://doi.org/10.1101/2021.08.25.21262596; this version posted August 28, 2021. The copyright holder for this preprint (which was not certified by peer review) is the author/funder, who has granted medRxiv a license to display the preprint in perpetuity.

All rights reserved. No reuse allowed without permission.

10

11

12

13

14 